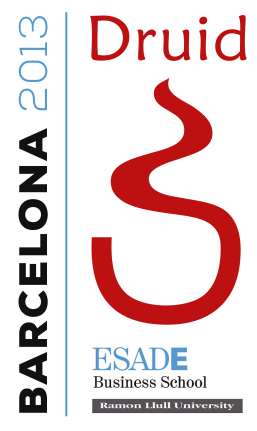

Paper to be presented at the

35th DRUID Celebration Conference 2013, Barcelona, Spain, June 17-19

\title{
Building design capabilities: a focus on knowledge systematisation within
}

\author{
firms \\ Beatrice D'Ippolito \\ Grenoble Ecole de Management, France \\ Management, Technology and Innovation Department \\ beatrice.dippolito@grenoble-em.com \\ Marcela Miozzo \\ The University of Manchester, UK \\ Manchester Business School \\ marcela.miozzo@mbs.ac.uk \\ Davide Consoli \\ CSIC-Universidad Politécnica de Valencia, Spain \\ INGENIO \\ davide.consoli@ingenio.upv.es
}

\begin{abstract}
Scholarly efforts within the evolutionary theories of the firm are increasingly attempting to bridge the micro and macro perspectives of capabilities research to learn more about the growth of the firm. This paper tackles this challenge by proposing a focus on the mechanisms of knowledge systematisation within firms, that is, those mechanisms of knowledge abstraction and transmission through different levels of aggregation. Traditional approaches have focused on the how routines and capabilities can trigger further learning. In this paper it is argued that a focus on learning events as a way to capture emerging knowledge can provide a better understanding of firms? learning dynamics. By analysing in-depth interview data regarding design-intensive home furnishing sectors in Italy, we focus on identifying those events that trigger relevant learning experiences. By ?relevant? we refer here to those events that express a coherent sequence of activities enabling the articulation of new product development-related knowledge. The findings yield an understanding of how a knowledge-intensive activity like design that cuts across a firm?s organisational structure fosters the emergence of capabilities, which originate from one-off solutions for a particular problem and can be further replicated to solve other types of problems.
\end{abstract}

Jelcodes:O32,- 


\title{
Building design capabilities: a focus on knowledge systematisation within firms
}

\author{
Beatrice D'Ippolito \\ Management, Technology and Innovation Department, Grenoble Ecole de Management \\ Grenoble, France \\ beatrice.dippolito@grenoble-em.com \\ Marcela Miozzo \\ Manchester Business School, The University of Manchester, United Kingdom \\ marcela.miozzo@mbs.ac.uk \\ Davide Consoli \\ INGENIO (CSIC-UPV), Valencia, Spain \\ davide.consoli@ingenio.upv.es
}

\begin{abstract}
Scholarly efforts within the evolutionary theories of the firm are increasingly attempting to bridge the micro and macro perspectives of capabilities research to learn more about the growth of the firm. This paper tackles this challenge by proposing a focus on the mechanisms of knowledge systematisation within firms, that is, those mechanisms of knowledge abstraction and transmission through different levels of aggregation. Traditional approaches have focused on the how routines and capabilities can trigger further learning. In this paper it is argued that a focus on learning events as a way to capture emerging knowledge can provide a better understanding of firms' learning dynamics. By analysing in-depth interview data regarding design-intensive home furnishing sectors in Italy, we focus on identifying those events that trigger relevant learning experiences. By 'relevant' we refer here to those events that express a coherent sequence of activities enabling the articulation of new product development-related knowledge. The findings yield an understanding of how a knowledgeintensive activity like design that cuts across a firm's organisational structure fosters the emergence of capabilities, which originate from one-off solutions for a particular problem and can be further replicated to solve other types of problems.
\end{abstract}

Keywords: capabilities, product design, learning event, knowledge systematisation

The opinions expressed in this paper are those of the authors. The usual caveat applies. 


\subsection{Introduction}

Ongoing debates within the theories of the firm are trying to bridge micro- and macrofoundations of the firm. Scholars have explored the importance of organisational routines and capabilities as firms' efforts to adapt their internal routines and know-how (learning processes) to new knowledge (Nelson and Winter, 1982, Nelson, 1991, Leonard-Barton, 1992, Winter, 2006). However, very often questions such as "How to differentiate lowerlevel from higher-level capabilities?" or "How do the ostensive and performative aspects of a routine link with higher-level capabilities?" distract the focus away from identifying specific practices or activities through which firms learn. Building from these contributions, the paper attempts to explore capability building through a focus on knowledge systematisation, and examines how and why this takes place through simple events.

In an attempt to bridge the micro- and macro-foundations of the firm (Nightingale, 2000, Dosi et al., 2008, Salvato and Rerup, 2011), the paper proposes a heuristic model that helps locate key mechanisms of knowledge articulation and absorption. The model allows the investigation of how the embeddedness of design expertise, which draws on a creative, knowledge-intensive activity, shapes the internal organisation of knowledge, for instance, through the establishment of new functions or the development of technical systems that can support the integration of knowledge sets that are difficult to formalise. Therefore, the paper contributes to the ongoing debate in the fields of organisation and strategic management: whilst firms' efforts to develop distinctive capabilities seem to affect how firms are organised internally (Lewin et al., 2011), the development of product design capabilities illustrates how emerging organisational capabilities lie on interdependencies across functions as well as activities of different nature. As a result of this, firms may need to reorganise by combining internal skills in a different way, but also by acquiring new ones if necessary, thus undermining the internal processes of knowledge abstraction and transmission.

To fulfil these aims, the paper is structured as follows. Section 2 develops a perspective of analysis and a framework that will be employed to explore knowledge systematisation mechanisms at micro level. Section 3 presents the empirical material and illustrates the main findings on the formation of product design capabilities. Section 4 discusses how the integration of a service activity that is cross-functional and knowledge-intensive in nature shapes firm specialisation. And Section 5 concludes the paper. 


\section{Systematisation of knowledge and formation of product design capabilities}

This section explores the theoretical tenets underpinning this research (Section 2.1) and presents the methodology developed to fulfil the stated research aims (Section 2.2).

\subsection{Knowledge systematisation underpinning the anatomy of organisational capabilities}

Firms are regarded as bundles of resources that need to be organised and managed in order to cope with the business environment (Penrose, 1959). Building on this, and integrating insights from Schumpeter (1934) with ideas from Alchian (1950), Hayek (1945), and Cyert and March (1963), Nelson and Winter (1982) view the firm as a profit-seeking entity whose primary activities consist of building and exploiting valuable knowledge assets (Teece, 2009). Nelson and Winter regard firm organisation as an important variable in its own right and their approach can be interpreted as the development of the Marshallian ideas in Penrose's theory (Loasby, 1991). Nelson and Winter (1982) assert that there are strong connections both between a firm's strategy and its organisational structure, and between the techniques commanded by a firm and its organisation. At the core of the evolutionary firm's functioning there are routinary activities, that is, units or 'chunks' of organised activity with a repetitive character or patterns of interactions that represent successful solutions for coping with a world of complexity and continuous change that preclude decisions and behaviours which maximise anything of importance. While acknowledging the uncertainties surrounding innovation, Nelson and Winter (1982) agree with Schumpeter that "organisations have welldefined routines for the support and direction of their innovative efforts" (1982:134).

Routines can be essential for the codification of specialised know-how and benefit from innovation, however, excessive routinisation can hamper a firm's ability to innovate. In order to cope with this dilemma firms develop specific capabilities, "high-level routines (or collection of routines) that, together with their implementing input flows, confer upon an organisation's management a set of decision options for producing significant outputs of a particular type" (Winter, 2000:983). ${ }^{1}$ Simply, routines are among the building blocks of organisational capabilities. Capabilities are deemed to fill the gap between intention and outcome in such a way that the outcome bears a definite resemblance to what was intended (Dosi et al., 2000b). They involve organised activity and their exercise is typically repetitious in substantial part; in other words, the "specific exercise may be intentional, but it may also be quite automatic" (Dosi et al., 2000b:2). The original use of the term 'capabilities' dates

\footnotetext{
${ }^{1}$ Some terminological issues are discussed in Dosi et al. (2000a).
} 
back to Richardson (1972), who made the fundamental point that organisations tend to specialise in activities for which their capabilities offer some comparative advantage, and that the pursuit of activities that are similar in the sense of drawing upon the same capabilities may lead a firm into a (coherent) variety of markets and a (coherent) variety of product lines (Dosi et al., 2008).

Scholars in the fields of organisation science and evolutionary economics are primarily interested in how capabilities are employed to introduce new ways of doing things, such as technologies, or ways of organising and governing work. It must be emphasised that capabilities are endogenous: to understand behaviours and what is learned, there is a need to understand the contribution of the firm itself, and not only external influences (Felin and Foss, 2011). ${ }^{2}$

This research suggests that the division of labour bridges the skills of individuals with organisational capabilities. Individuals within a firm are assigned a set of tasks and presumably they have the skills to carry them out. The division of labour defines the subproblems each individual will have to cope with, and the boundaries of the environment they have to focus on, so that each individual knows only a part of what is required to solve the problem, while the team as a whole has the knowledge required for the solution (Nelson and Winter, 1982, Egidi, 1992). For this reason, firms have to decide whether to rely on the market or to acquire the necessary capabilities to produce in-house. These are information or knowledge costs that Langlois (1992) defines as "dynamic transaction costs". It is these costs, he explains, "that permit the notion of 'capabilities', unlike the classical or neoclassical notion of production costs, to help explain the boundaries of the firm". In short, these are "the costs of persuading, negotiating, coordinating and teaching outside suppliers", which translates as "the costs of not having the capabilities you need when you need them" (Langlois, 1992:113).

Despite a general belief within the capability-based view of the firm that firms know how to do things, the building blocks of organisational strategy and the relations between them are not completely understood (Dosi et al., 2000a, Dosi et al., 2008). While agreeing with Dosi et al. (2000a) that organisational capabilities constitute a fairly large-scale unit of analysis,

\footnotetext{
${ }^{2}$ The authors argue that, if a child and his 'pet bee' are exposed to the same environment and stimuli, there would still be a difference in the capabilities: the child would not develop the navigational ability of the bee, and the bee would not develop language capabilities, despite uniform environmental stimuli. In short, radically different behavioural and capability outcomes would readily be evident (Felin and Foss, 2011:246).
} 
trying to disentangle intentions and conscious purposes from more habitual and automatic activities remains a challenge. Whilst so far the focus has been on individual firms trying to develop capabilities as they need them, we insist that there exist mechanisms whereby the knowledge produced at firm level is shared with the external environment in order to reduce (though interaction) the risk associated with innovation activities. We argue that a focus on these mechanisms may represent a point of entry in the exploration of industrial growth.

By selecting a cross-functional activity like design, this paper explores how mechanisms of knowledge systematisation and transmission within firms shape the formation of organisational capabilities. We focus on the evolution of the Italian home furnishing sectors, the history of which provides a context for exploring issues such as the co-evolution of different knowledge bases (e.g., treatment of wood, plastics, and iron) and the subsequent establishment of organisational practices. Details of the research design follow below.

\subsection{A proposed methodology to explore knowledge systematisation: a focus on events}

It is argued that the formation of organisational capabilities within firms can be observed through events that capture knowledge systematisation mechanisms. Knowledge systematisation is referred to as the process of abstraction of operative principles with the effect of expanding the remit of practical routines that had been conceived initially for a specific purpose (Rosenberg, 1976). This definition would account also for the tacit component characterising knowledge-intensive activities, which would be neglected by an exclusive focus on codification processes.

This aim called for methods appropriate to identifying the particular mechanisms of opportunity creation, organisational emergence and evolution, including expansion and interruptions in dynamic processes in particular institutional contexts (Langley, 1999, Van de Ven and Poole, 2005, Chiles et al., 2007). Design as the locus where creativity gives shape to the idea seems a particularly suitable frame within which these processes can be explored. Moreover, the pervasive nature of design is another justification for its selection as the empirical domain. This pervasiveness is vertical: design is not manufacturing but it is bound with it. Design as the set of criteria for defining the structural properties of manufactured goods is a necessary component. Similarly, design is not entertainment but is also bound to it. The evolution of the aesthetic aspects of design implies greater disposable income, more sophistication and specialisation in tastes and production. Design is also pervasive in horizontal terms, which also renders design interesting from an empirical point of view. By 
nature, design is hard to deconstruct. Taking as an example a chair that is characterised by a specific design, it would be possible to learn about its mechanics and underlying structure once all the pieces are taken apart but this would destroy the chair's mechanisms and design. This means that the very processes of creation and the modification of the design object intersect with a vast array of knowledge sets (Walsh, 1996). As a result, exploring design activities, which cut across different levels of products, firms and industries organisation, gives the chance to explore the co-evolution of different sets of activities, which in a firm context, translates into the co-evolution of individual- and firm-level skills sets.

For the purpose of this paper, we understand design as the set of routines aimed at meeting functional or aesthetic product specifications, and which rely on properties of raw materials or scientific principles learned via formal and informal mechanisms. Design activities apply to diverse categories of tasks to the effect of conferring coherence to a set of disperse elements of a problem that, just like raw materials, do not yield a clear structure in the absence of an intentional architecture.

The research context is the home furnishing sectors, which comprise the following industries: wooden furniture, lighting systems, kitchen furniture, living room furniture, bathroom furniture, office furniture, and contract design. ${ }^{3}$ We rely on a combination of primary and secondary data sources to design an exploratory (multiple) case study which could explore the connection among the relevant technological, organisational, and institutional advancements of these sectors.

Data collection followed a loose timeline throughout which there has been some overlap with data analysis, an approach that helped enrich the validity of data. It also facilitated the adjustment of objectives that are pre-established in a deductive way, with elements that are identified later on, according to an inductive logic (Eisenhardt, 1989). Face-to-face interviews were conducted with chief executives and senior managers of different departments (i.e., product development, $R \& D$, marketing, and art direction) in eight furniture manufacturing firms at different points in time between April 2010 and June 2011. The eight firms originate from a bigger sample (thirteen firms) built for another project that investigated the processes of institutionalisation processes of knowledge systematisation mechanisms. Their consensus to follow-up in the research process allowed us to gain an in-depth understanding of the

\footnotetext{
${ }^{3}$ From both a theoretical and a methodological point of view it would be incoherent to treat innovation in materials in a furniture firm akin to innovation in fabrics taking place within a fashion design studio: the knowledge base is different and it would be difficult to test existing theories or develop new principles.
} 
dynamics specific to the firms. In building the sample, we sought for diversity among them. We chose firms among the exhibitors at the Salone Internazionale del Mobile 2010 assuming that these firms' experience along with their history of frequent new product developments would represent an indicator of their success in design capability building. The core business of the sampled firms is furniture manufacturing. Some of them were first established as workshops for the production of wooden furniture, some others as subcontractors for larger manufacturing firms (see list of sampled firms in Table 1; see details of the interviews in Appendix, Table A.1).

Table 1 about here

Interview data were gathered to investigate the following themes: the steps that characterise the internal NPD process and the dynamics of interaction within (between individuals and/or business functions) and beyond the organisational boundaries; the influence exerted by design knowledge upon the specialisation of individuals, the formation of firm capabilities, and the patterns of interaction with external actors; how extant mechanisms of interaction and knowledge sharing have been modified, reorganised or integrated with new ones during the development of design expertise.

We focused on the learning events and experiences firms undergo when they undertake design activities and aimed at identifying how existing skills sets and routines have been modified or integrated with new ones, concentrating on the sequences of events in time and context, paying particular attention to their temporal ordering, interactions and institutional environment (Langley, 1999, Tsoukas and Chia, 2002, Chiles et al., 2007, Ravasi and Stigliani, 2012) (see list of events in Appendix A, Table A.2). The set of categories was developed by drawing on the extant design and innovation literature, ${ }^{4}$ and their validity was partly judged by drawing on the organisational routines and capabilities literature (Becker, 2004, Dosi et al., 2008, Salvato and Rerup, 2011) and partly on the design and innovation literature (Walsh et al., 1992, Walsh, 1996, Perks et al., 2005). By considering events as the instances at which new learning is generated and a subsequent action is undertaken (see

\footnotetext{
${ }^{4}$ The set of categories and the literature of reference has been the following: NPD process (Perks et al., 2005); other internal sources (Perks et al., 2005; Bruce et al., 1995); technology (Walsh et al., 1992); strategy-making (Gorb and Dumas, 1987); customer base (Perks et al., 2005); external resources (institutions) (Cooper ad Press, 1995; Maskell et al., 2006); network (Verganti, 2003; Utterback et al., 2007).
} 
learning experiences discussed later in Section 3.2.2 and illustrated in Table B.2), our approach resembles the tradition of process methods of combining theory-driven constructs (grounded theory strategy) with data-driven categories (alternate template strategy) with the final aim of preserving data accuracy and synthesis (Langley, 1999). Due to the uncertain location of design activities within firms, we decided to maintain a loose definition of events according to which learning can take place at the individual, department, or firm level, which would enable us to achieve the ultimate objective, that is, the identification of capability building processes.

Due to the highly tacit nature of design activities, it is difficult to operationalise constructs such as routines or other types of standard procedures, the authors focused on the firm's effort to develop core competencies in design. To this end, competencies were understood as the knowledge sets that distinguish and provide competitive advantage to firms and followed the definition provided by Leonard-Barton (1992), which recognises that organisational capabilities rest on complex patterns of cultural, relational, human and technological resources and whilst it is grounded in the empirical evidence, it is also in line with the idea that capabilities are processes that leverage specific resources (Eisenhardt and Martin, 2000, Verona and Ravasi, 2003). As Ravasi and Stigliani (2012) point out, in the case of design capabilities, insights could be generated through in-depth investigation of social practices and structures (Salvato, 2003, 2009).

Firms' efforts to develop design expertise were observed throughout the four conventional phases of NPD (idea generation, production, market placement, and feedback gathering), a perspective that recognises product innovation as an organisational process especially important in the practical investigation of dynamic capabilities (Eisenhardt and Martin, 2000, Bruni and Verona, 2009). In this case, the aim was to explore how the embeddedness of design expertise affects firms at the heart of their innovation processes. This simple definition of NPD is deemed to incorporate the basic understanding of a design process as starting off with the generation of new ideas, then proceeding with the manufacturing and subsequent placement in the market, and the 'final' phase of gathering the feedback. Learning events were identified and mapped in a matrix that intersects the elements of core competencies listed above on one side, and the four phases of NPD on the other (Figure 1). As illustrated later in the finding section, this visual mapping exercise facilitates the simultaneous representation of different dimensions of capability building (Miles and Huberman, 1994, 
Langley, 1999), thus a better understanding of the question at stake. The focus on learning mechanisms allows the capturing of feedback loops, which are important for the trial-anderror iterations of designers' activities.

Figure 1 about here

In order to operationalise these concepts, data analysis sought to address the following questions: (i) How do firms absorb the information generated by design activities (e.g., via technical systems or procedures)? (ii) Once new information is available, which capabilities have been developed to facilitate the articulation and embeddedness within the extant organisational structure? Learning events were categorised and mapped in terms of source of learning and of experience that such learning generated. With regard to the former, the focus was on those sources that advanced the firm's knowledge and supported a design-related decision. With regard to the experiences, the focus was on 'what' the firm created, implemented, or modified as a result of a particular learning event, and the related categories were grounded in the data. In this second case, data analysis started with open coding of the collected information, which provided a first structure. Once the within-case analysis was finalised, cross-case analysis was conducted to detect communalities and differences in terms of product design capability development across the sampled cases (Eisenhardt and Graebner, 2007, Yin, 2009). ${ }^{5}$

To sum up, the processes of how firms absorb the information generated through undertaking design activities were identified (i.e., the focus has been on the momentum of learning); then attention shifted to the element of capability that was developed by firms to systematise new sets of knowledge.

\section{Findings}

Section 3.1 conducts a horizontal analysis of learning processes within firm and focuses on six different contexts in which actors, physical resources, structures and systems, and company culture adjust to embedding the new expertise. Section 3.2 takes on a vertical perspective instead and brings to light the connections between firm evolution and the

\footnotetext{
${ }^{5}$ The set of categories regarding the learning experience is illustrated in the findings section of the paper (Section 3.2.2) and discussed accordingly.
} 
development of product design capabilities, both in terms of sources of learning and generated experience.

\subsection{A horizontal approach to analysing product design capability building}

The current section illustrates how firms' infrastructure has evolved in order to embed specialised design expertise by exploring how internal know-how, technical and managerial systems, and value systems have been influenced by learning processes. Each of the subsections below explores in more detail what a firm's design capability impinges on and, although firms on their own may provide limited data reflecting the development of specific abilities, the findings from the eight firms constituted a solid ground on which to draw a picture of their efforts of design capability building. At the end of each subsection, there follows an adaptation of the general model earlier presented that represents the knowledge and learning dynamics behind product design capability.

\subsubsection{Fostering cooperation between the Production and the Product Development} functions

Design has emerged as an activity to be integrated at specific stages of the product development process (Perks et al., 2005). The empirical evidence has highlighted how efforts to integrate the activities undertaken by the Production department within the NPD process led to increasing decision-making for the teams within the production floors and more specifically a larger involvement of the NPD director in the development of the brief. This, in turn, entailed broadening the knowledge set available during the product ideation, and therefore, to reduce the risk of failure.

As specified in the research design section, the sampled firms redesigned their strategy in order to exploit design as a lever of competitive advantage. As part of this evolution, their production infrastructure has been integrated with new resources: design emerged to be very much intertwined with the engineering and production dimensions of product development, despite it being regarded as a matter of aesthetics. Interview data drew attention to a series of actions that had been undertaken to combine these different dimensions of product design. These firms were traditional family businesses, with a top-down approach to their strategy. This attitude has changed with the explicit intent of developing design as a key asset to develop distinctive competencies by establishing collaborations with external designers or art directors. Field data points to how these relationships influenced the organisational culture 
and in particular, the interaction between the Production department (machine-intensive) and other departments.

First, the Production Director is directly involved in the briefing stage, for instance, by providing input to the prototyping team (prototyping workshops are most likely located within the Production department). The contribution of the Production Director is more substantial during the concept development phase: in some cases, the internal procedure for managing the development and industrialisation of new products has been redesigned and the Production Director has been recognised a larger share of responsibility in terms of decisionmaking (Boffi, Dieffebi and Presotto). In other instances, the Production Director provides input regarding the adoption of new materials or techniques (s)he has learned from interacting with suppliers (Molteni\&C and Valcucine). Second, in order to strengthen the generation of feedback that is essential for the industrialisation of ideas, the prototyping workshop has been given a more prominent role. Considered as the firm's lung, this place binds the firm's production capability with the techniques introduced through NPD projects. As Valcucine's R\&D Director stated, "both the Designer and I visit the prototype workshop regularly, we spend even more time there than sitting at our desks. " 6 Third, and similarly important, management teams believe that staff members from the production floors should be involved in the development of new products due to their in-depth, practical understanding of how new products are made. Firms have come to believe that this is a potentially valuable input to NPD, for instance with regard to installing new machinery equipment or adopting a new material or production software. Given these premises, a more intensive collaboration with the Production function has been established through different initiatives such as: set up of notice boards in the production floor, where details of new product developments are posted and kept updated (Lago and Valcucine); creation of an online community for all the employees, this included members from the production floor (Lago); or employee empowerment through training courses on 'The adoption of the Lean Production System (LPS)' for the members of the Production department (Boffi, Lago and Valcucine).

The development of this dimension of design capability has caused (i) a change in the values and norms that govern interactions within the firm, and (ii) the establishment of informal mechanisms for the generation of new knowledge. The development of this dimension of design capability has caused (i) a change in the values and norms that govern interactions

\footnotetext{
${ }^{6}$ Interview with R\&D Director, Valcucine, 1 June 2011.
} 
within the firm, and (ii) the creation of informal mechanisms for knowledge creation (see illustration of this process in Appendix, Figure B.1).

\subsubsection{Carrying out product testing in-house}

Empirical evidence shows that, due to the important role played by product testing in guaranteeing high quality products, firms are motivated to build this expertise in-house. This has entailed developing specialised skills about materials, technologies, production techniques, and product quality. Product testing is considered as an important activity to determine if the product functions properly and reliably (Cooper and Kleinschmidt, 1986), and guarantee that industry standards (e.g., quality or materials) are adhered to. Interview data illustrates that this is an essential stage of product development for a twofold reason: from the market point of view, consumers expect top quality because they are purchasing non-perishable, luxury products. More importantly, from the innovation point of view, product testing is essential because it yields further understanding of how a particular prototype will function under certain conditions, for instance, how resistant a chair is to weight.

The participants in the current research agreed on the importance of conducting these tests early in the prototype stage in order to reduce errors and resource waste during the industrialisation phase. Except Dieffebi and Magis, in which case members from the Product Development department tend to collaborate with external suppliers for product testing, the remaining firms conduct most of the needed tests in-house through specialised machines or laboratories, which are established as independent units. Table 2 lists the most common formal tests that these firms conduct in order to insure a high quality production. Some of these tests are enforced by international standard regulations (e.g., Ente Nazionale Italiano di Unificazione [UNI] and American National Standards Institute [ANSI]) and are carried out by CATAS SpA, a research institute based in Italy and established for testing materials and technologies that are employed in wood and furniture manufacturing. ${ }^{7}$ This laboratory relies on a team of forty experts, including chemists, engineers and mathematicians, whose aim is to enhance product quality and reliability. Interestingly, firms also carry out tests that are not mandatory (e.g., tests 'd' and 'f' in Table 2), yet they are designed "to guarantee that

\footnotetext{
${ }^{7}$ Another institute that carries out similar types of tests is COSMOB, a technology centre specifically specialised in the sector of wooden furniture (www.cosmob.it).
} 
exogenous factors will not damage the product functionality or design and cause any trouble for the end user." 8

Table 2 about here

Testing also takes place in an informal way during the actual development of the prototype, and does not necessarily lead to a 'happy ending'. One of the interviewees described the process of developing a shower plate and the need to interrupt it following some attempts to install it. Due to both the characteristics of the material used (nylon) and the technology used (rotational press), the product was deforming if exposed to hot water for too long. "Clearly the product was not meeting Boffi's quality standards, and we were forced to stop the development of the product". ${ }^{9}$ The graphical illustration of the learning dynamics underpinning this dimension of product design capability can be found in Appendix, Figure B.2.

\subsubsection{Gathering and managing relevant feedback}

In order to benefit from new insights that feedback loops may generate (Vincenti, 1990, Perks et al., 2005), firms seem to develop a value system that can determine the source, the nature and the way of absorbing both internal and external feedback. Empirical evidence shows that, in moving towards a more structured organisation and management of NPD, firms have felt the need to gather systematically relevant feedback that may affect the process of product design and development. While feedback gathering and management happen in different ways, there is consistency in the way firms have demonstrated a proactive approach to modifying their internal procedures in order to collect insightful feedback and transfer them to the relevant department, as needed. Table 3 summarises how these changes took place. With regard to internal feedback, it is shown how informal interactions can be as significant as those procedures that are formally implemented. In terms of external feedback, firms perceive these approaches to be more effective in communicating their design strategy values and advertising products to consumers.

\footnotetext{
${ }^{8}$ Interview with Product Development Director, Valcucine, 1 June 2011.

${ }^{9}$ Interview with Marketing and Quality Director, Boffi, 20 May 2010.
} 
Table 3 about here

The graphical illustration of the learning dynamics underpinning this dimension of product design capability can be found in Figure B.3 (Appendix), which attempts to illustrate the direction in which feedback is deployed and managed.

\subsubsection{Fostering experimentation}

Whilst much scholarly effort has been dedicated to how firms can develop organisational creativity (Woodman et al., 1993), it is still difficult to understand where this creativity derives from and how it impacts on the experimenting activities undertaken by firms. The case study evidence highlighted that design knowledge pervades the firm through different channels, and it becomes essential to seize emerging stimuli and exploit them to the advantage of firm competitiveness. To this end, firms have developed new, informal ways of knowledge creation that could nurture the initial creative phase of the NPD process and facilitate the engagement of different business functions. Having in mind the objective of "featuring products with a unique design", firms have modified the way product development is thought and planned, for instance by encouraging a stricter collaboration between the Art Director and members of the Product Development department. ${ }^{10}$ A more established practice consists of attending events that are not particularly related to the home furnishing sectors, such as the Shoe Fair in Bologna, ${ }^{11}$ or a presentation of the properties of magnesium in Israel. ${ }^{12}$ Most interviewees emphasised that these events are important because they facilitate the collection of information regarding existing materials or technologies that are most likely to open up new venues in furniture manufacturing.

Creativity is also fostered through the creation of spaces, either in a formal or informal way, within which employees can learn about design. For instance, Valcucine, specialising in the design and development of kitchen furniture, has established an internal library, which holds 738 books to date whose subjects include arts, creativity, communication, marketing, gardening, literature, environment, organisational culture, economics, aesthetics, architecture, sociology, creative writing, and philosophy. ${ }^{13}$ It is interesting to notice that no design discipline appears in the list. As one of the interviewees stated, "it is essential that we learn

\footnotetext{
${ }^{10}$ Interview with R\&D Director and internal Designer, Boffi, 9 June 2011.

${ }^{11}$ Interview with R\&D Director, Molteni\&C, 7 June 2011.

${ }^{12}$ Interview with materials expert, Valcucine, 1 June 2011.

${ }^{13}$ Last updated on 01/06/2011.
} 
about the different spheres within which our consumers can operate, and we need to be creative in this process!",14

In other words, in order to develop this creative element of the design capability, firms encourage engagement with other disciplines that could relate to design and nurture its innovative activities. "If a firm wishes to 'do design', then the cultural level needs to be high" ${ }^{15}$ Interview data suggests that technical competencies are not enough, open mindedness and continuous curiosity are essential. Design is in fact characterised by a strong intangible component, product innovation is not only about the physical artefact, but also where it is placed, how it is communicated, and what the rationale behind its conception is. A graphical illustration of these dynamics can be found in Appendix, Figure B.4.

\subsubsection{Developing and benefiting from a network}

Design is a social phenomenon that relies significantly on the exchange of resources or ideas between different actors. The importance of establishing a network of relationships with external actors is recognised as an important factor for design-driven firms' competitiveness (Verganti, 2003, Utterback et al., 2007). This section investigates how firms develop and benefit from these relationships; the setup of managerial systems is deemed necessary for the absorption of new knowledge, especially during the idea generation phase, that is, when the management decides which expertise to develop and technologies to adopt. At a more general level, the firm's ability to belong to a solid network generates a direct benefit for the firm's reputation and visibility.

Within the sample, it can be observed that actors such as designers, architects, suppliers, sales points, and retailers play a key role in supporting the firm's network of relationships.

Increasingly external R\&D centres or experts such as management consultants or engineering managers are becoming also some of the major partners (Boffi, Lago and Valcucine). The deployment of long-term relationships with these actors is perceived as contributing to enhancing a firm's visibility and reputation for 'being innovative', and therefore the potential for fruitful collaborations. More detailed findings regarding these relationships are reported in Table 4 below. A series of examples demonstrates how, while networking is conventionally understood as strength, for those firms that are trying to build a reputation based on a design(and technology-) intensive approach, it becomes essential. As one interviewee admitted, "if

\footnotetext{
${ }^{14}$ Interview with President and Art Director, Valcucine, 1 June 2011.

${ }^{15}$ Interview with President and Art Director, Lago, 23 May 2011.
} 
Preliminary draft: please do not quote without the authors' permission.

you also rely on the external environment, then you have better chances to be competitive within the market". ${ }^{16}$

Table 4 about here

The network plays a key role in those firms whose core business is to (i) design and develop the prototype, and (ii) to transform and assemble semi-finished components that have been co-developed at the suppliers' site with moulds being owned by the contracting firm (Magis and Valcucine). In these scenarios, the alignment between the firm's expertise and the knowhow gathered through the network is essential for technological advancement. The graphical illustration of these mechanisms can be found in Appendix, Figure B.5.

\subsubsection{Communicating the meaning and values of design}

Empirical evidence emphasised that firms must (and do) make an effort to communicate the meaning of a specific product design. To this end, they have in fact set up new systems for creating and controlling knowledge during the market placement of the product and the subsequent phase of feedback gathering. These changes also call for an adaptation of the value and norm systems across the whole organisation.

Design generates value not only through the physical objects reaching the end consumer, but also through influencing the innovativeness of the actors involved in the NPD process. Interviewees agreed that 'conventional' marketing techniques are not suitable for an organisation that is trying to persuade the consumers about the value behind a particular design. Innovation is crucial to build visibility, "but then, it is important to communicate it to the consumers. ${ }^{17}$ In this section, firms' efforts to develop the social dimension of the design capability is explored, one that can support the proper communication of a firm's products to its customers.

Retailers constitute one of the key loops within the value chain because they are in direct contact with the end-user, ${ }^{18}$ and firms aim at deploying value through their distribution network. From an organisational perspective, they have developed partnerships to manage

\footnotetext{
${ }^{16}$ Interview with Marketing and Quality Director, Boffi, 20 May 2010.

${ }^{17}$ Interview with President (co-founder) and internal Designer, Luceplan, 18 May 2010.

${ }^{18}$ As the Marketing director in Lago stated, "the most important match of the league is played between the enduser and the retailer!"
} 
and coordinate the activity of the retailers, for instance by collaborating on the architecture and interior design of the selling points. Second, from the product delivery point of view, some firms have designed and delivered courses to train retailers and assemblers about product design rationales, technological innovations, and the firm-level design vision (Dieffebi, Molteni\&C, Presotto and Valcucine).

Firms' efforts have also been addressed at connecting with consumers, overcoming the absence of direct contact with them. Empirical evidence suggested how, in a society where social media play an important role in communication, blogs and other types of communication tools represent a means to establish a direct connection with consumers. Furthermore, it has become established practice to provide consumers with a series of manuals (that the retailer would hand over to the customer) containing guidelines as to how materials should be treated or products cleaned (Molteni\&C, Presotto and Valcucine). These manuals are publicly available for download on the company website. The graphical illustration of these transmission mechanisms can be found in Appendix, Figure B.6. In summary, it should be emphasised that the learning processes abstracted above are not a clear-cut representation of how the design capability is being generated. In fact, due to the firms' changing organisational structure, some events would generate learning that nurtures more than one process. The analysis of the development of core competencies (LeonardBarton, 1992) throughout the NPD process helps identifying at which point of the NPD learning emerges and which actions firms undertake to systematise the particular learning experience.

\subsection{A vertical approach to investigating the learning dynamics behind product design capability building}

This section attempts to build a transversal picture of what has been presented in Section 3.1 by investigating the sources of learning that supported firms during their process of product design capabilities and how the experience attached to this learning has influenced firm evolution. The heuristic framework used to illustrate the foundations of design capability building lies on the assumption that firms learn from their mistakes, and the loops of feedback that develop throughout (Nelson and Winter, 1982, Vincenti, 1990). The model sheds light on how, while a new routine, or process that will become a routine, is emerging, the underpinning learning mechanisms generate a wider impact on the organisational strategy. In this section we discuss (i) the types of learning sources that supported the 
development of the design capability (Section 3.2.1) and (ii) the learning experiences firms underwent during this process (Section 3.2.2). Particular emphasis is placed on investigating how these experiences have shaped innovation beyond the single product and influenced firms' behaviour (Levitt and March, 1988), with the final aim of envisaging approaches to design capability building.

\subsubsection{Learning sources behind a firm's product design capability}

The findings presented so far suggest that developing product design capabilities 'invisibly' binds together the innovation underpinning a specific project with the firm's increasing specialisation and product innovation strategy. This section sheds light on the sources that generate relevant learning for this process to take place. Three main types of sources are identified:

1. Technological and operational sources of learning encompass the learning that is deployed and utilised during the design and development of new products; examples of these sources are represented by NPD process, other internal resources, technology, and customer base.

2. Strategic sources of learning account for those events that influence a firm's strategic approach, such as strategy-making and customer base. In general, events under this category emphasise the role of design as a strategic lever whereby product innovation is not only about technology advancement, but also about making an effort to align the product strategy with the firm's vision.

3. Social sources of learning account for the relational component of product design capabilities and encompass the learning generated during the firm's interaction with external actors. Examples of this last group are external resources and network.

Empirical evidence points to the wide breadth of these sources, spanning from productspecific elements to elements of strategy, and external resources. Moreover, some events are the outcome of formalised strategies (e.g., modular production triggered by the implementation of the LPS), while others are of occasional ones (e.g., Valcucine's choice to employ an anti-vibrant material common in textiles to protect the washing machine while running the spinning cycle). This analytical perspective is new because, by focusing on the sources of learning, it identifies where and how firms can develop expertise for the development of product design capabilities. In support of this Table B.1 (Appendix B) 
identifies, for each of the processes introduced in Section 3.1, the events that are directly connected with the underlying learning, their source, and the business functions involved. The table highlights how the systems developed to create and control knowledge and are needed to routinise sets of activities that rely on a broad range of sources. This process is dynamic in nature because continuous learning loops engender shifting cross-functional boundaries and lead to the establishment of new competencies. These dynamics bring to light the learning mechanisms that are generated during the process of product design capability building and the nature of the feedback loops that are triggered as a result of this learning (e.g., from managerial systems to employees' skills, and to the systems of value and norms). In general, these findings draw attention to two important aspects of firm growth. First, firms rely on learning events that may not necessarily fall in the conventional strategic plan, yet they provide insight on the NPD and, more generally, are means of acquiring specialised knowledge, design know-how in this case. Second, the heterogeneous nature of learning points to the increasing importance of cross-functional projects and competencies for undertaking design activities instead of a departmentalised view of firms' specialisation.

The main challenge rests with understanding how systematic these learning processes are. It is widely accepted that learning generates future innovation through routinisation to the extent that it generates relevant experiences for the firm and triggers the establishment of practices that can help systematise learning (March et al., 1991, Zollo and Winter, 2002, Helfat and Peteraf, 2003). In order to substantiate the constructs identified in Table B.1, a focus on learning experiences is essential to understand how firms learn from instances, or a group of instances, which will lead to the routinisation of an underlying set of activities, thus challenging the traditional understanding of routines as creating organisational inertia (Feldman and Pentland, 2003). In line with this argument, Section 3.2.2 discusses how experiences influence the dynamics of knowledge articulation introduced earlier in the paper.

\subsubsection{Learning experiences supporting product design capability}

The need to articulate experience-based learning has been widely regarded by extant literature (Levitt and March, 1988, Cohen and Levinthal, 1990, Zollo and Winter, 2002, Teece, 2009). This section explores how the learning experiences are embedded into the firms' governance and evolution, and contribute to the development of product design capabilities. As reported in Table B.2 (Appendix), the case evidence brings to the fore nine types of experiences that firms underwent; the table describes in detail what firms learn about 
under each of the categories. For instance, an experience about product aesthetics means that a particular event generated insights about the product appearance or styling.

By combining the experiences with the processes of knowledge articulation identified in Section 3.2, it is possible to envisage different behaviours across the sample of firms under investigation, which lead to two firm archetypes: Firm Archetype A (Luceplan, Molteni\&C and Valcucine) and Firm Archetype B (Boffi, Dieffebi, Lago and Presotto). ${ }^{19}$ There seems to be a certain consistency across the sample regarding the development of both technical systems for supporting all the phases of NPD and means for knowledge creation during the market placement of new products. Moreover, most firms agreed that the establishment of a Communication business function is key to sharing the values inherent to design and supporting the development of an innovation strategy that could be coherent both within and beyond organisational boundaries. Yet, there are major differences between the two archetypes.

Firstly, Firm Archetype A conceives design as a strategic tool for creating new products (i.e., product level) and developing a coherent innovation strategy (i.e., firm level). This means that design knowledge is applied to (i) product-related issues, for as much as the development of new products is concerned, (ii) strategy-making, which regards design as contributing to firm specialisation, and (iii) the organisational culture, through the system of values and meanings the firm is trying to communicate. In contrast interview data from Firm Archetype $\mathrm{B}$ revealed that they define design mainly in terms of product aesthetics and functionality, with the impact of product design upon the strategic and operational dimensions of product innovation coming into focus at a later stage. This leads to a second observation regarding firms' dynamics of specialisation and the acquisition of specialised skills aimed at deploying design activities. Firm Archetype B, while focusing on issues regarding the product or the manufacturing process, would recruit experts in materials or operations management, for example in order to tackle technical aspects of the NPD process new to the firm. On the other hand, Firm Archetype A, while already being specialised in a particular segment of the design discipline, would perhaps put further effort into increasing the degree of internal specialisation. This may entail different actions, such as developing expertise in a new design

\footnotetext{
${ }^{19}$ As one may notice, Magis is not included in either of the archetypes. Due to its unique approach to developing design expertise, that is, based on the founder's creativity, not a designer himself, and the continuous strive for collaborations with innovative designers, the firm is an outlier with regard to its approach to innovation strategy.
} 
area (e.g., interaction design) or benefiting from the contribution of the materials expert not only for a particular product, but also as a way to diffuse specialised knowledge within the firm.

Thirdly, the two archetypes differ with regard to how firms exploit their networking. Firm Archetype A would rely on networking in order to complement the specialised know-how already present in-house and develop new partnerships for technology development or target otherwise inaccessible market segments (e.g., exploiting the partner's distribution channels). However, networking is essential for the survival of firms in Archetype B. Firm Archetype B in fact would rely on the external network for different reasons such as conducting basic activities of new product design and developments at the suppliers' site (e.g., trial-and-error activities) or marketing the product through collaborations with the retailers (Firm archetype AA would train the network of retailers with internal training courses instead). In other words, the relational aspect of design is important for both firm archetypes, yet the mechanisms implemented to operationalise it differ.

Table 5 below compares and contrasts the two archetypes by specifying which elements of a firm's 'core capability' between Employee Knowledge and Skills (EKS), Technical Systems (TS), Managerial Systems (MS) and Value and Norms (VN) are mobilised in order to deploy design know-how. The table highlights how, per each of the archetypes, the change in one or more of the components mentioned above supports the systematisation of knowledge and contributes to capability building. For instance, with regard to fostering experimentation within the firm, it is possible to notice that Firm Archetype A tends to develop internal repositories of knowledge which could nurture future research, whereas Firm Archetype B tends to establish collaborations with external actors (e.g., education institutions or local communities) to increase the opportunities for innovation. More generally, the table draws attention to the specific instances whereby mechanisms of knowledge generation are systematised and transmitted to higher level of abstraction. The table emphasises how the multi-faceted nature of design activities prepares the way for different paths for developing product design capabilities, for instance, internal specialisation for Firm Archetype A versus specialisation through external collaborations for Firm Archetype B, in other word, how organisational strategy comes about under the capability view of the firm (Dosi et al., 2008). It must be noted that the sampled firms can boast of an international reputation, and their presence in the foreign market ranges from 40 to 70 per cent of their annual turnover. 
Table 5 about here

\section{Discussion}

The findings shed light on the mechanisms of knowledge abstraction and transmission that emerge and develop within and beyond firm boundaries. The main contribution consists of showing how learning events can be a trigger for the development of firm competencies and capability building. By mapping the events in a heuristic model that observed changes in any of the elements of core competencies throughout the NPD process, it was possible to categorise the sources of learning (technological and operational, strategic, and social) and to identify the mechanisms of knowledge articulation that facilitate the embeddedness of the new expertise within the existing organisational structure.

The analysis has highlighted that these mechanisms originate from the interplay between division of knowledge and division of work tasks within firms, and extend through interorganisational relations. This insight is of particular relevance to learn about the mechanisms of formalisation of knowledge-intensive activities like design, the innovativeness of which generates benefits beyond the single project. Furthermore, the knowledge systematisation also translated into the emergence of learning processes that are specific to each firm and, as argued in this context, contribute to product design capability building.

Through a focus on how the evolution of firm's core competencies leads to the development of (product design) capabilities, it was also possible to bring to light the connection between core competencies of the firm on the one hand, and routine activities and organisational capabilities on the other. The present discussion attempts to argue that this relationship is not trivial. By building on Zollo and Winter's (2002) concept of deliberate learning, the current research provides an analytical understanding of how learning is articulated through a firm's core competencies (Leonard-Barton, 1992). Whilst scholars in the past have often taken this latter notion for granted, in fact (future) learning will depend on the learning accumulated through experience and the investment made in those core capabilities (Nelson, 1994). The findings illustrated earlier in the paper delve into this dimension. They show how organisational capabilities are connected with firms' core competencies and, as a result, how 
the systematisation underpinning knowledge-intensive activities can shape the formation of organisational capabilities and the very pattern of firms' specialisation.

The trigger point for capability building is represented by learning events, which can be rooted in the firm's technological infrastructure, strategic approach, or interaction with external actors (e.g., suppliers, consumers, or sector-specific institutions). These events generate, through the firm's core competencies, learning regarding different domains, such as product characteristics, strategy, expertise, and issues regarding the organisational structure; the generated experience bounces back to the firm's competencies and indirectly shapes the formation of product design capabilities. The same events can also trigger growth through the NPD process of the firm, a process that generates a direct impact on product design capabilities. The 'final' step of both paths is the influence exerted by the capabilities on the original set of competencies of the firm. As suggested, the renewed competencies will shape the selection of future sources of learning and trigger future processes of capability development, which - depending on the effects generated by learning experiences - may lead to refining the existing capabilities or introducing new ones. These processes can also be expressed in terms of change taking place at different levels (e.g., source of learning, extant know-how, or experience), as represented in Figure 2 below.

Figure 2 about here

Beyond the specific domain of product design, the findings bring to the fore two main aspects of capability development. First, that organisational capabilities rest on complex patterns of cultural, relational, human, and technological resources (Leonard-Barton, 1992, Ravasi and Stigliani, 2012), and the (six) processes introduced in Section 3.1 are not simply routine activities. The co-evolution of learning processes and feedback loops signals firms' ability to master complex routines, and therefore higher-level capability (Nelson, 2009). ${ }^{20}$ Second, the evidence contributes to the debate on how firms accumulate and articulate specialised expertise either formally, through the establishment of a business function, or informally,

\footnotetext{
${ }^{20}$ As Nelson (2009) makes clear, Nelson and Winter (1982) did not mean to underplay either the often complex and sophisticated technological aspect of some routines, or the role of skills and knowledge required of individual humans who were involved in the 'doing'. Instead, developing an effective team operation of a routine requiring is a challenging problem, and once achieved, requires maintenance. So, "mastery of a complex routine is an organisational capability" (Nelson, 2009:11).
} 
through systematisation of learning and variation of the core competencies (Zollo and Singh, 2004). The growth of the firm does not only rely on the acquisition of new skills and their integration within existing business functions, but there are mechanisms of learning underlying intra- and inter-organisational relationships drawing attention to how firms evolve to accommodate this learning.

This discussion paves the way for the identification of a series of lessons regarding the development of product design capabilities and the formation of organisational capabilities more generally.

\section{Lessons on the development of product design capabilities}

The above findings suggest that product design capabilities stem from, and are nurtured by, technological and operational, strategic, and social types of sources. The archetypes profiled above highlight how emphasis on different aspects (such as product innovation strategy in Firm Archetype A versus product aesthetics in Firm Archetype B) may lead firms to draw their competitive advantage on different success factors (internal specialisation in Firm Archetype A versus networking in Firm Archetype B). Adaptive renewal is premised on a series of activities and events, which rely upon local resources first, and then are refined through interactions within and beyond organisational boundaries by facilitating the replication of sets of activities, and therefore the improvement of firm performance (Salvato, 2009).

The breadth of product design capabilities spans from product-specific elements to elements of strategy or external resources. In particular, the findings suggest that design acts as an 'invisible' thread binding together the innovation underpinning a specific project, the innovation leading a firm to specialise in a certain area, and the innovation strategy set out by firms. Such a thread relies on the occurrence of learning events that facilitate the systematisation of tacit knowledge and allow the translation of context-specific solutions to other projects and/or business functions (Nightingale, 2000). In doing so, design expertise shapes the structure and functions of other departments, for instance, by strengthening the role of the Production department in the context of NPD, by shaping the system of values that the firm relies on, or by aligning the firm's strategy with the innovation- and design-related choices, confirming that design is pervasive along both the vertical and horizontal dimensions of firm and industry organisations. 
The contribution by Zollo and Winter (2002) served to envisage the processes of knowledge abstraction and articulation via a focus on learning experiences and to develop a framework for the systematic building of product design capabilities at firm level. The heuristic model suggested that, in order to develop dynamic capabilities originating from a knowledgeintensive activity, it is important to focus on the incremental learning and fine-tuning of relevant day-to-day activities in the firm. In practice, this means focusing on individual skills and how these are transferred to the structures, practices and resources that underpin capabilities at organisational level (Ravasi and Stigliani, 2012).

\section{Lessons on the formation of firm capabilities}

Three main lessons can be drawn from the case study evidence with regard to the formation of firm capabilities. First, the development of organisational capabilities sits on both learning processes and extant core competencies of the firm, including systems of values and norms. This provides an overall understanding of how learning is systematised through the firm's core competencies. Given that core competencies summarise the effectiveness of firmspecific problem-solving procedures (Dosi and Marengo, 2000), combining core competencies with capabilities allows the assessment of how firms, whilst improving their problem-solving capability, preserve their specificities. To this extent, this paper adds to the contribution by Zollo and Winter (2002), who explore how dynamic capabilities develop through the co-evolution of three mechanisms, namely, tacit accumulation of past experience, knowledge articulation, and knowledge codification processes. The added value of this research consists of showing how the characteristics of firms' organisational structure and culture (embedded in the four elements that make up the core competencies) play a role throughout the process of capability formation by interacting with specific problem-solving tasks that need to be mastered for the generation of effective learning behaviours (and experiences).

Second, the findings contribute to the literature that argues for the existence of complementarities and interdependencies between external routines and internal, less observable, routines supposedly supporting the effectiveness of the former (see discussion on absorptive capacity by Lewin et al., 2011). The findings highlight that capabilities that draw on knowledge-intensive, cross-functional activities like design do not entail a mere reorganisation of the firm's structure as Lewin et al. (2011) suggested when exploring the development of absorptive capacity capability. The development of design capabilities draws 
attention to the existence of interdependencies across functions as well as activities of different kinds. To this end, firms need to reorganise themselves by combining internal skills in a different way, acquiring new ones if necessary and question the very same process of product innovation. The focus upon design appreciates the value of feedback not only at product level (Vincenti, 1990), but also at the organisational level, through an understanding of firms' specialisation patterns. Feedback is important for various reasons, namely: to align the objectives of the Production function with those of the Product Development function, to absorb relevant knowledge from the customer base, to build a stable relationship with external actors, or to enhance the value of design at both product and firm level. Bringing to light these aspects would contribute to the literature on capability building, which tends to focus on routines and capabilities by neglecting institutionalisation processes regarding other types of innovative practices.

Third, and in connection with the previous point, the research adds to the contribution by Verona and Ravasi (2003). By exploring processes of continuous product innovation in an outstanding company within the hearing-aid industry, they argue that dynamic capabilities are not the individual resources, practices, or structures that characterise NPD or strategic decision-making, but the higher order knowledge-related processes that are performed through the combinations of these elements. This research proposes a way to identify these higher order knowledge-related processes through a focus on learning dynamics at the individual, business function, or firm level. It also draws attention to the organisational and institutional processes that qualify firms' product design capabilities as dynamic. Capabilities emerge as comprising components that, combined in specific ways, will facilitate the replication of practices for the articulation and systematisation of specialised know-how (e.g., use of media channels to communicate directly with the customer base, or regular crossfunctional brainstorming meetings). Not all learning events become a formal routine, rule, or procedure, but all events may potentially contribute to the institutionalisation of a capability.

\section{Conclusion}

The findings illustrated earlier (re-)bring to light the relationship between core competencies and organisational capabilities. Through a focus on two fundamental pillars of dynamic capabilities development, sources of learning and learning experience, the main contribution of this paper consists of illustrating the analytical mechanisms through which core competencies are interrelated with learning processes at multiple levels, and how these in turn 
shape the formation of organisational capabilities. The framework developed allows the location of mechanisms of knowledge systematisation regarding activities that are knowledge-intensive, that is, activities that are characterised by a body of knowledge hard to formalise, and multi-disciplinary in nature, which in a firm or industry context means crossing the boundaries between business functions, firms, and sectors. This has been further supported by the employment of process research techniques, which drew attention on the importance of events when observing learning processes and on the very multi-dimensional anatomy of capabilities. By selecting a knowledge-intensive activity (like design) that cuts across firm's organisational structure, the paper illustrated how learning processes that emerged, at first, as one-off solutions to specific problems, can be replicated to solve future problems (Vincenti, 1994, Nightingale, 2000, Salvato, 2003) through the advancement of the firm's core competencies. The increasingly wider scope of these solutions widens their domain of applicability to solve firm-level problems and, over time, become a firm capability (Dosi et al., 2008).

In light of this argument, an important contribution of the paper consists of providing an understanding of how service-based capabilities can shape the evolution and create value for manufacturing firms (Teece et al., 1997, Eisenhardt and Martin, 2000) in a similar fashion to how Bruni and Verona (2009) explored if and how market knowledge can be a venue for value creation in science-based firms.

Conceptual problems such as distinguishing between operational and higher order capabilities, and distinguishing between capabilities which rely on incremental learning processes, and those that presuppose dramatic new knowledge trajectories remain (EasterbySmith et al., 2009). Whilst this is believed to be one of the limitations of this study, it is proposed that future effort could explore further the capabilities identified in this research and develop deeper understanding of the difference between operating, dynamic, and core capabilities, and more generally, of how micro- and macro-foundations of firm evolution can be bridged. 


\section{References}

Alchian, A. A. (1950) Uncertainty, evolution, and economic theory. Journal of Political Economy, 58(3), 211-221.

Becker, M. C. (2004) Organizational routines: a review of the literature. Industrial and Corporate Change, 13(4), 643-677.

Bruce, M. and Biemans, W. G. (1995) Product development: meeting the challenge of the designmarketing interface, Chichester, Wiley.

Bruni, D. S. and Verona, G. (2009) Dynamic marketing capabilities in science-based firms: an exploratory investigation of the pharmaceutical industry. British Journal of Management, 20(n/a), S101-S117.

Chiles, T. H., Bluedorn, A. C. and Gupta, V. K. (2007) Beyond creative destruction and entrepreneurial discovery: a radical Austrian approach to entrepreneurship. Organization Studies, 28(4), 467-493.

Cohen, W. M. and Levinthal, D. A. (1990) Absorptive capacity: a new perspective on learning and innovation. Administrative Science Quarterly, 35(1), 128-152.

Cooper, R. G. and Kleinschmidt, E. J. (1986) An investigation into the new product process: steps, deficiencies, and impact. Journal of Product Innovation Management, 3(2), 71-85.

Cooper, R. G. and Press, M. (1995) The design agenda. A guide to successful design management, Chichester, Wiley.

Cyert, R. M. and March, J. G. (1963) A behavioural theory of the firm, Oxford, Blackwell Press.

Dosi, G., Coriat, B. and Pavitt, K. (2000a) Competences, capabilities and corporate performance. Laboratory of Economics and Management (LEM). Pisa: Laboratory of Economics and Management, Dynacom Series.

Dosi, G., Faillo, M. and Marengo, L. (2008) Organizational capabilities, patterns of knowledge accumulation and governance structures in business firms: an introduction. Organization Studies, 29(8-9), 1165-1185.

Dosi, G. and Marengo, L. (2000) Some elements of an evolutionary theory of organizational competences. In: Dosi, G. (ed.) Innovation, Organization and Economic Dynamics: Selected Essays. Cheltenham, UK: Edward Elgar Publishing.

Dosi, G., Nelson, R. R. and Winter, S. G. (2000b) Introduction: the nature and dynamics of organizational capabilities. In: Dosi, G., Nelson, R. R. and Winter, S. G. (eds.) The nature and dynamics of organizational capabilities. Oxford: Oxford University Press.

Easterby-Smith, M., Lyles, M. A. and Peteraf, M. A. (2009) Dynamic capabilities: current debates and future directions. British Journal of Management, 20(n/a), S1-S8.

Egidi, M. (1992) Organizational learning, problem solving and the division of labour. In: Simon, H. A., Marris, R. L. and Egidi, M. (eds.) Economics, bounded rationality and the cognitive revolution. Aldershot: Edward Elgar.

Eisenhardt, K. M. (1989) Building theories from case study research. Academy of Management Review, 14(4), 532-550.

Eisenhardt, K. M. and Graebner, M. E. (2007) Theory building from cases: opportunities and challenges. Academy of Management Journal, 50(1), 25-32.

Eisenhardt, K. M. and Martin, J. A. (2000) Dynamic capabilities: what are they? Strategic Management Journal, 21(10/11), 1105-1121.

Feldman, M. S. and Pentland, B. T. (2003) Reconceptualizing organizational routines as a source of flexibility and change. Administrative Science Quarterly, 48(1), 94-118.

Felin, T. and Foss, N. J. (2011) The endogenous origins of experience, routines, and organizational capabilities: the poverty of stimulus. Journal of Institutional Economics, 7(2), 231-256.

Gorb, P. and Dumas, A. (1987) Silent design. Design Studies, 8(3), 150-156.

Hayek, F. A. (1945) The use of knowledge in society. American Economic Review, 35(4), 519-530.

Helfat, C. E. and Peteraf, M. A. (2003) The dynamic resource-based view: capability lifecycles. Strategic Management Journal, 24(10), 997-1010. 
Iansiti, M. and Clark, K. B. (1994) Integration and dynamic capability: evidence from product development in automobiles and mainframe computers. Industrial and Corporate Change, 3(3), 557-605.

Langley, A. (1999) Strategies for theorizing from process data. The Academy of Management Review, 24(4), 691-710.

Langlois, R. N. (1992) Transaction-cost economics in real time. Industrial and Corporate Change, 1(1), 99-127.

Leonard-Barton, D. (1992) Core capabilities and core rigidities: a paradox in managing new product development. Strategic Management Journal, 13(Special Issue), 111-125.

Levitt, B. and March, J. G. (1988) Organizational learning. Annual Review of Sociology, 14(1), 319340.

Lewin, A. Y., Massini, S. and Peeters, C. (2011) Microfoundations of internal and external absorptive capacity routines. Organization Science, 22(1), 81-98.

Loasby, B. J. (1991) Equilibrium and evolution - An exploration of connecting principles in economics, Manchester, Manchester University Press.

March, J. G., Sproull, L. S. and Tamuz, M. (1991) Learning from samples of one or fewer. Organization Science, 2(1), 1-13.

Maskell, P., Bathelt, H. and Malmberg, A. (2006) Building global knowledge pipelines: the role of temporary clusters. European Planning Studies, 14(8), 997-1013.

Miles, M. B. and Huberman, A. M. (1994) Qualitative data analysis, Thousand Oaks, CA, Sage.

Nelson, R. R. (1991) Why do firms differ, and how does it matter? Strategic Management Journal, 12(S2), 61-74.

Nelson, R. R. (1994) The co-evolution of technology, industrial structure and supporting institutions. Industrial and Corporate Change, 3(1), 47-63.

Nelson, R. R. (2009) Routines as technologies and as organizational capabilities. In: Becker, M. C. and Lazaric, N. (eds.) Organizational routines: advancing empirical research. Cheltenham, UK: Elgar, 11-25.

Nelson, R. R. and Winter, S. G. (1982) An evolutionary theory of economic change, London, Belknap Press.

Nightingale, P. (2000) The product - process - organisation relationship in complex development projects. Research Policy, 29(7-8), 913-930.

Penrose, E. T. (1959) The theory of the growth of the firm, Oxford, Basil Blackwell.

Perks, H., Cooper, R. and Jones, C. (2005) Characterizing the role of design in new product development: an empirically derived taxonomy. Journal of Product Innovation Management, 22(2), 111-127.

Ravasi, D. and Stigliani, I. (2012) Product design: a review and research agenda for management studies. International Journal of Management Reviews, Forthcoming(n/a), 1-25.

Richardson, G. B. (1972) The organisation of industry. The Economic Journal, 82(327), 883-96.

Rosenberg, N. (1976) Technological change in the machine tool industry, 1840-1910. In: Rosenberg, N. (ed.) Perspectives on Technology. New York: M. E. Sharpe, 9-31.

Salvato, C. (2003) The role of micro-strategies in the engineering of firm evolution. Journal of Management Studies, 40(1), 83-108.

Salvato, C. (2009) Capabilities unveiled: the role of ordinary activities in the evolution of product development processes. Organization Science, 20(2), 384-409.

Salvato, C. and Rerup, C. (2011) Beyond collective entities: multilevel research on organizational routines and capabilities. Journal of Management, 37(2), 468-490.

Schumpeter, J. (1934) The Theory of Economic Development, Cambridge, Harvard University Press.

Teece, D. J. (2009) Dynamic Capabilities and Strategic Management: Organizing for Innovation and Growth, Oxford, Oxford University Press.

Teece, D. J., Pisano, G. and Shuen, A. (1997) Dynamic capabilities and strategic management. Strategic Management Journal, 18(7), 509-533.

Tsoukas, H. and Chia, R. (2002) An organizational becoming: rethinking organizational change. Organization Science, 13(5), 567-582. 
Utterback, U., Vedin, B. A., Alvarez, E., Ekman, S., Sanderson, S. W., Tether, B. S. and Verganti, R. (2007) Design-inspired innovation, Singapore, World Scientific Publishing.

Van de Ven, A. H. and Poole, M. S. (2005) Alternative approaches for studying organizational change. Organization Studies, 26(9), 1377-1404.

Verganti, R. (2003) Design as brokering of languages: innovation strategies in Italian firms. Design Management Journal, 14(3), 34-42.

Verona, G. and Ravasi, D. (2003) Unbundling dynamic capabilities: an exploratory study of continuous product innovation. Industrial and Corporate Change, 12(3), 577-606.

Vincenti, W. G. (1990) What engineers know and how they know it. Analytical studies from aeronautical history, London, The John Hopkins University Press.

Vincenti, W. G. (1994) Variation-selection in the innovation of the retractable airplane landing gear: the Northrop 'anomaly'. Research Policy, 23(5), 575-582.

Walsh, V. (1996) Design, innovation and the boundaries of the firm. Research Policy, 25(4), 509-529.

Walsh, V., Roy, R., Bruce, M. and Potter, S. (1992) Winning by design: technology, product design and international competitiveness, Oxford, Blackwell Publishers.

Winter, S. G. (2000) The satisficing principle in capability learning. Strategic Management Journal, 21(10/11), 981-996.

Winter, S. G. (2006) Toward a neo-Schumpeterian theory of the firm. Industrial and Corporate Change, 15(1), 125-141.

Woodman, R. W., Sawyer, J. E. and Griffin, R. W. (1993) Toward a theory of organizational creativity. Academy of Management Journal, 18(2), 293-321.

Yin, R. (2009) Case study research: design and methods, California, Thousand Oaks - 4th Edition.

Zollo, M. and Singh, H. (2004) Deliberate learning in corporate acquisitions: post-acquisition strategies and integration capability in U.S. bank mergers. Strategic Management Journal, 25(13), 1233-1256.

Zollo, M. and Winter, S. G. (2002) Deliberate learning and the evolution of dynamic capabilities. Organization Science, 13(3), 339-351. 


\section{Tables}

\section{Table 1: Sampled firms}

\begin{tabular}{|c|c|c|c|c|c|c|c|c|}
\hline Firm & Location & $\operatorname{Size}(1)$ & $\begin{array}{l}\text { Location of } \\
\text { Design }^{(2)}\end{array}$ & $\begin{array}{l}\text { Marke } \\
\text { home }\end{array}$ & $\begin{array}{l}\text { position } \\
\text { foreign }\end{array}$ & $\begin{array}{l}\text { Area(s) of } \\
\text { expertise }\end{array}$ & Design expertise & Highlights \\
\hline Boffi & Milan & Large & ED & $35 \%$ & $65 \%$ & $\begin{array}{l}\text { Living rooms, } \\
\text { bathrooms }\end{array}$ & $\begin{array}{l}\text { R\&D department ( } 3 \text { members } \\
\text { of staff); Product Develop- } \\
\text { ment department ( } 4 \text { engine- } \\
\text { ers); collaborations with } \\
\text { renowned external designers }\end{array}$ & $\begin{array}{l}\text { Developing internal expertise in } \\
\text { lighting; member of the Fonda- } \\
\text { zione Altagamma, a foundation } \\
\text { that gathers all the Italian luxury } \\
\text { companies known for their design }\end{array}$ \\
\hline Dieffebi & Treviso & Medium & ED & $28 \%$ & $72 \%$ & Office, contract & $\begin{array}{l}\text { Product Development depart- } \\
\text { ment ( } 3 \text { engineers); collabora- } \\
\text { tions with external designers }\end{array}$ & $\begin{array}{l}\text { Specialised in the development } \\
\text { and manufacturing of metal- } \\
\text { based furniture }\end{array}$ \\
\hline Lago & Padua & Medium & ID & $\mathrm{n} / \mathrm{a}$ & $\mathrm{n} / \mathrm{a}$ & $\begin{array}{l}\text { Living rooms, } \\
\text { Bathrooms }\end{array}$ & $\begin{array}{l}\text { Design department ( } 3 \text { desi- } \\
\text { gners, including the President, } \\
\text { the firm's Art Director); Pro- } \\
\text { duct Development department } \\
\text { ( } 5 \text { technical experts, } 1 \text { mate- } \\
\text { rials expert) }\end{array}$ & $\begin{array}{l}\text { Longstanding tradition in the ma- } \\
\text { nufacturing of wooden furniture, } \\
\text { then switch to plastics and newer } \\
\text { materials; particularly oriented } \\
\text { towards spurring a creative-thin- } \\
\text { king environment across the dif- } \\
\text { ferent departments }\end{array}$ \\
\hline Luceplan & Milan & Medium & I\&ED & $20 \%$ & $80 \%$ & Lighting systems & $\begin{array}{l}\text { Product Development depart- } \\
\text { ment (industrial designers and } \\
\text { engineering designers); colla- } \\
\text { boration with few, trusted ex- } \\
\text { ternal designers }\end{array}$ & $\begin{array}{l}\text { Strong specialisation in one seg- } \\
\text { ment (lighting design); collabora- } \\
\text { tions with R\&D research centres } \\
\text { of multinationals (significant col- } \\
\text { laboration with Philips) }\end{array}$ \\
\hline Magis & Treviso & Medium & ED & $15 \%$ & $85 \%$ & $\begin{array}{l}\text { Living rooms } \\
\text { contract }\end{array}$ & $\begin{array}{l}\text { Product Development depart- } \\
\text { ment; regular collaboration } \\
\text { with external designers (em- } \\
\text { phasis placed on their reputa- } \\
\text { tion) }\end{array}$ & $\begin{array}{l}\text { Main customer target: high-end } \\
\text { market segment; specialisations } \\
\text { recently developed in new areas }\end{array}$ \\
\hline
\end{tabular}


Table 1 (continued)

\begin{tabular}{|c|c|c|c|c|c|c|c|c|}
\hline Firm & Location & Size(1) & $\begin{array}{l}\text { Location of } \\
\text { Design }^{(2)}\end{array}$ & $\begin{array}{l}\text { Marke } \\
\text { home }\end{array}$ & $\begin{array}{l}\text { position } \\
\text { foreign }\end{array}$ & $\begin{array}{l}\text { Area(s) of } \\
\text { expertise }\end{array}$ & Design expertise & Highlights \\
\hline Molteni\&C & Milan & Large & ED & $45 \%$ & $55 \%$ & $\begin{array}{l}\text { Living rooms, } \\
\text { office, bedrooms } \\
\text { contract }\end{array}$ & $\begin{array}{l}\text { Product Development depart- } \\
\text { ment; Art Director; tendency } \\
\text { to collaborate with an establi- } \\
\text { shed network of designers }\end{array}$ & $\begin{array}{l}\text { Major Italian group within the } \\
\text { home furnishing sector, with a } \\
\text { worldwide reputation; strong col- } \\
\text { laboration with external R\&D } \\
\text { centres; attempt to create syner- } \\
\text { gies between the different busi- } \\
\text { ness units (e.g., living room, } \\
\text { office, kitchen) }\end{array}$ \\
\hline $\begin{array}{l}\text { Presotto } \\
\text { Industrie }\end{array}$ & Pordenone & Medium & ED & $60 \%$ & $40 \%$ & $\begin{array}{l}\text { Bedrooms, living } \\
\text { rooms, contract }\end{array}$ & $\begin{array}{l}\text { Product Development depart- } \\
\text { ment; regular collaboration } \\
\text { with external designers }\end{array}$ & $\begin{array}{l}\text { Strong connection between the } \\
\text { R\&D and the Marketing depart- } \\
\text { ments; highly engaged with the } \\
\text { local network of actors (e.g., edu- } \\
\text { cation institutions, sector-specific } \\
\text { trade associations) }\end{array}$ \\
\hline Valcucine & Pordenone & Medium & ID & $60 \%$ & $40 \%$ & $\begin{array}{l}\text { Kitchen, living } \\
\text { Rooms }\end{array}$ & $\begin{array}{l}\text { Product Development depart- } \\
\text { ment; internal Art Director; } \\
\text { Design department }\end{array}$ & $\begin{array}{l}\text { Highly proactive firm in terms of } \\
\text { environment-friendly kitchen fur- } \\
\text { niture; regular collaborations with } \\
\text { external R\&D centres in place }\end{array}$ \\
\hline
\end{tabular}


Table 2: Examples of product tests in home furnishing manufacturing

$\begin{array}{ll}\text { Component } & \text { Test } \\ \text { Material } & \begin{array}{l}\text { a. Resistance to weather conditions } \\ \text { b. Resistance to pressure } \\ \text { c. Reaction to heat }\end{array} \\ & \begin{array}{l}\text { d. Reaction to excessive light exposure } \\ \text { Painting }\end{array} \\ \text { f. Resistance to heat } \\ \text { Mechanisms } & \text { g. Usage (e.g., no. of times a drawer is opened) } \\ & \begin{array}{l}\text { h. Resistance to weight } \\ \text { i. Reaction to pressure }\end{array}\end{array}$




\section{Table 3: Gathering of internal and external feedback}

\section{INTERNAL FEEDBACK}

Mechanisms and procedures set up (i) to facilitate the interaction among those participating in the NPD process and (ii) to benefit from the deriving learning.

- Meetings between the Directors have become a regular practice aimed discussing new ideas or the 'first impression' of ongoing projects. "The aim is to screen through the proposal in order to assess the products, and to analyse internal needs for new ideas and then decide which projects to pursue" (R\&D Director, Molteni\&C, 7 June 2011).

- The Board of Directors may decide to stop a NPD project. "In a couple of instances, we did not have the capacity to produce the minimum quantity to break-even and, sadly, we had to interrupt the product development” (Production Director, Presotto, 13 May 2011)

Prototype considered as a key turning point for learning.

- Once the first prototype is realised, the interaction with the designer continues for additional negotiations about the product specifications. Despite the availability of 3D software, "the manual ability is still crucial, and the physical prototype remains the point at which mistakes are spotted and the product is modified, either in functionality or aesthetics" (R\&D and Marketing Director, Presotto, 13 May 2011).

- Fairs and exhibitions represent opportunities to test the product's functionality and, when needed, to simplify or modify it. "Even ourselves, when we assemble it, we learn firsthand about the problems end-users could be facing” (Marketing Director, Dieffebi, 6 June 2011; R\&D and Marketing Director, Presotto, 13 May 2011).

Employees intervening during the manufacturing and distribution of the product.

- Suppliers are considered 'internal actors' since they provide valuable input and/or feedback during the development of the brief or the prototype, which often leads to the co-development of new technologies.

- Assemblers are invited to participate actively in the development of the prototype in order to advise on various aspects, such as physical layout of subcomponents or other technical details (Interview with Product Development Director, Valcucine, 1 June 2011).

\section{EXTERNAL FEEDBACK}

The customer base is the firm's most important source of external feedback.

- The market research conducted during the brainstorming stage is mainly a signpost for NPDs because surveying user needs during the definition of the brief is not conducive of innovation. "Design is about fulfilling unexpressed needs" (Marketing and Quality Director, Boffi, 20 May 2010).

- The Salone Internazionale del Mobile as a way to test the prototype ready for industrialisation, though some interviewees agreed that "it is too crowded, which prevents establishing a meaningful (first) contact with the customer" (President and Art Director, Valcucine, 11 May 2010).

- Development of alternative ways to approach consumers such as events at the firm's showroom, located in Milan (Boffi and Valcucine), or furnishing a flat with the firm's furniture products as if it were a real home as well as an object for exhibition (e.g., Lago Appartamento by Lago).

Post-sale service, set-up by firms with a different degree of formalisation.

- Type of feedback helping to enhance the performance of the faulty product (e.g., by drawing attention to specific sub-components or features) (Interview with R\&D and Marketing Director, Presotto, 31 May 2011)

- Feedback benefiting complementary projects in which similar mechanisms, materials, or technologies are employed (Interview with Marketing Director, Dieffebi, 6 June 2011; interview with Marketing Director, Lago, 23 May 2011; interview with Product Development Director, Valcucine, 1 June 2011). 
Table 4: Types of partners within home furnishing firms' network of relationships

\begin{tabular}{|c|c|}
\hline Partner(s) & Case study evidence \\
\hline Freelance designers & $\begin{array}{l}\text { Six out of the eight sampled firms have admitted that they } \\
\text { receive a "significant amount of design proposals from external } \\
\text { designers on a regular basis, from five to ten every week" } \\
\text { (Boffi, Dieffebi, Lago, Luceplan, Molteni\&C and Valcucine). } \\
\text { Their aim is for their product to be industrialised by the firm or } \\
\text { to promote their product and skill portfolio. }\end{array}$ \\
\hline Suppliers & $\begin{array}{l}\text { The relationship with the firm goes beyond the manufacturing of } \\
\text { a particular sub-component. Suppliers can constitute a precious } \\
\text { source of innovation through the adoption of a new material or } \\
\text { development of a specific technology. }\end{array}$ \\
\hline External R\&D centres & $\begin{array}{l}\text { Belonging to an active network opens up new venues for } \\
\text { collaboration. In this case, either privately run or connected with } \\
\text { a university, the relationship "is about exchanging and debating } \\
\text { our personal known-how" (Interview with R\&D Director, } \\
\text { Molteni\&C, 7 June 2011). Two examples are worth mentioning. } \\
\text { First, Molteni\&C collaborates with Armani in the production of } \\
\text { 'Armani Kitchen', a partnership that relies on Molteni\&C's } \\
\text { expertise in kitchen manufacturing (through Dada, one of the } \\
\text { subsidiaries) and Armani's network in America (access to } \\
\text { fabrics new to the European market). Second, the partnership } \\
\text { between Luceplan and Philips, an operation through which } \\
\text { Philips could conduct basic and applied R\&D in LED } \\
\text { technology, one of Luceplan's core competencies, and Luceplan } \\
\text { could benefit from Philips's specialised expertise and global } \\
\text { distribution network. }\end{array}$ \\
\hline Education institutions & $\begin{array}{l}\text { Students within professional schools, universities, and } \\
\text { specialisation schools have the chance to practice their skills } \\
\text { through internships or placement; more importantly, firms } \\
\text { exploit these occasions to scout talent and possibly engage in a } \\
\text { long-term working relationship with them. }\end{array}$ \\
\hline
\end{tabular}




\section{Table 5: Firm Archetype A versus Firm Archetype B}

\section{Product design capability}

1. Exploiting the expertise of the Production department throughout the NPD process

2. Carrying out product testing in-house

3. Gathering and managing relevant feedback

4. Fostering experimentation

5. Developing and benefiting from a network

\section{Firm Archetype A}

TS Access to the online community for employees of the Production department

VN Stronger connection between the prototyping workshop and the Production department

MS Establishment of laboratories for conducting tests or managing other types of processes

VN Informal interactions with different actors (e.g., assemblers, retailers)

EKS Provision of a Customer Care service

MS Internal repositories of knowledge (e.g., library)

MS Cross-functional brainstorming meetings

Informal networking with communities of creative professionals

MS Engaging in R\&D with industrial partners

6. Communicating the meaning (and value) of design

\section{Firm Archetype B}

MS Formal involvement of the Production director during briefing

MS Setting up of notice boards in the Production plant

EKS Key role of the internal prototyping workshop

MS Building a direct contact with the customer base EKS Provision of a Customer Care service

MS Engaging with education institutions

MS Engaging with local communities

MS Organising training workshops

MS Collaborations with suppliers for technology development

EKS Selection of expertise through collaboration with education institutions

VN Fostering cross-functional sharing information to increase awareness

MS Exploiting the benefits of social media 


\section{Figures}

Figure 1: Analytical framework used to locate events behind product design capability building

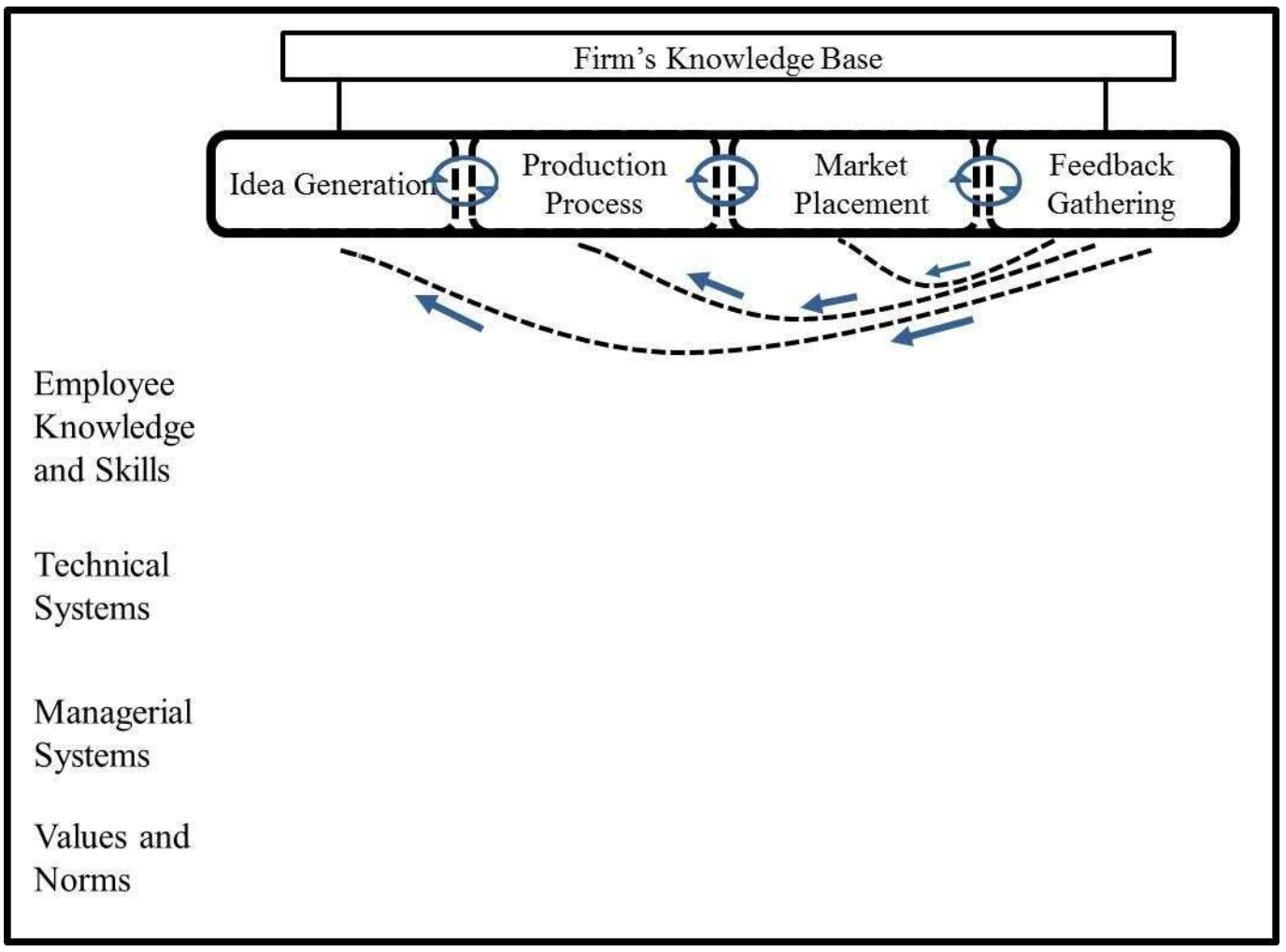

Figure 2: Core competencies and organisational capabilities of the firm

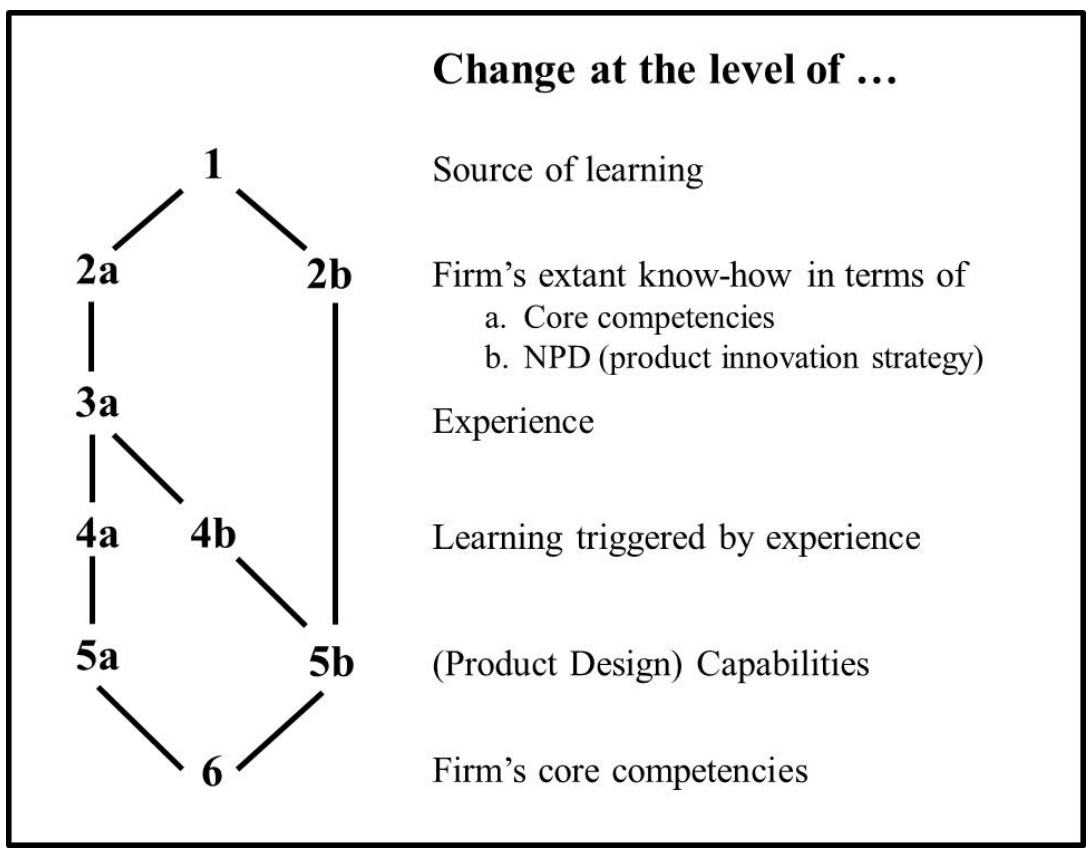




\section{Appendix A}

\section{Table A.1: Details of interviews conducted within the sampled firms}

\begin{tabular}{|c|c|c|c|c|}
\hline Firm (no. interviews) & Date & Informant & Description & Length \\
\hline Boffi (3) & $\begin{array}{l}20 / 05 / 2010 \\
09 / 06 / 2011\end{array}$ & $\begin{array}{l}\text { Marketing and Quality Director } \\
\text { Marketing and Quality Director, Art Director }\end{array}$ & $\begin{array}{l}\text { Face-to-face, Milan (firm's showroom) } \\
\text { Face-to-Face, Milan (firm's site) }\end{array}$ & $\begin{array}{l}71 \mathrm{~min} \\
161 \mathrm{~min}\end{array}$ \\
\hline Dieffebi (4) & $\begin{array}{l}11 / 05 / 2010 \\
06 / 06 / 2011\end{array}$ & $\begin{array}{l}\text { Marketing Director } \\
\text { Marketing Director, Product Development Director, } \\
\text { Member of the Product Development department }\end{array}$ & $\begin{array}{l}\text { Face-to-face, Treviso (firm's site) } \\
\text { Face-to-face, Treviso (firm's site) }\end{array}$ & $\begin{array}{l}60 \mathrm{~min} \\
100 \mathrm{~min}\end{array}$ \\
\hline Lago (8) & $\begin{array}{l}14 / 05 / 2010 \\
23 / 05 / 2011\end{array}$ & $\begin{array}{l}\text { Marketing Director } \\
\text { Marketing Director, Materials Expert, Communication } \\
\text { Director, Member of the Product Development depart- } \\
\text { ment department (x2), Operations Director, President } \\
\text { and Art Director }\end{array}$ & $\begin{array}{l}\text { Face-to-face, Milan (firm's showroom) } \\
\text { Face-to-face, Padua (firm's site) }\end{array}$ & $\begin{array}{l}95 \mathrm{~min} \\
160 \mathrm{~min}\end{array}$ \\
\hline Luceplan (3) & $\begin{array}{l}18 / 05 / 2010 \\
08 / 06 / 2011\end{array}$ & $\begin{array}{l}\text { President (Co-founder and internal designer) } \\
\text { (New) President, Art Director }\end{array}$ & $\begin{array}{l}\text { Face-to-face, Milan (firm's site) } \\
\text { Face-to-face, Milan (firm's site) }\end{array}$ & $\begin{array}{l}65 \mathrm{~min} \\
60 \mathrm{~min}\end{array}$ \\
\hline Magis (2) & $\begin{array}{l}10 / 05 / 2010 \\
12 / 11 / 2010\end{array}$ & $\begin{array}{l}\text { President (Founder) } \\
\text { External Designer }\end{array}$ & $\begin{array}{l}\text { Face-to-face, Treviso (firm's site) } \\
\text { Phone interview }\end{array}$ & $\begin{array}{l}80 \mathrm{~min} \\
72 \mathrm{~min}\end{array}$ \\
\hline Molteni\&C (2) & $\begin{array}{l}06 / 05 / 2010 \\
07 / 06 / 2011\end{array}$ & $\begin{array}{l}\text { Marketing Director } \\
\text { R\&D Director }\end{array}$ & $\begin{array}{l}\text { Face-to-face, Milan (firm's showroom) } \\
\text { Face-to-face, Milan (firm's site) }\end{array}$ & $\begin{array}{l}45 \mathrm{~min} \\
152 \mathrm{~min}\end{array}$ \\
\hline Presotto Industrie (3) & $\begin{array}{l}13 / 05 / 2010 \\
31 / 05 / 2011\end{array}$ & $\begin{array}{l}\text { R\&D and Marketing Director } \\
\text { R\&D and Marketing Director, Production Director }\end{array}$ & $\begin{array}{l}\text { Face-to-face, Pordenone (firm's site) } \\
\text { Face-to-face, Pordenone (firm's site) }\end{array}$ & $\begin{array}{l}56 \mathrm{~min} \\
173 \mathrm{~min}\end{array}$ \\
\hline Valcucine (6) & $\begin{array}{l}11 / 05 / 2010 \\
01 / 06 / 2011\end{array}$ & $\begin{array}{l}\text { President (Co-founder) and Art Director } \\
\text { President (Co-founder) and Art Director, Communication } \\
\text { Director, Product Development Director, R\&D Director } \\
\text { and Materials Expert, Prototyper }\end{array}$ & $\begin{array}{l}\text { Face-to-face, Pordenone (firm's site) } \\
\text { Face-to-face, Pordenone (firm's site) }\end{array}$ & $\begin{array}{l}55 \mathrm{~min} \\
171 \mathrm{~min}\end{array}$ \\
\hline
\end{tabular}




\section{Table A.2: Events triggering learning}

\section{List of events triggering learning ( $A-Z$ order)}

Adoption of technologies

Brainstorming

Brief of the designer

Collaboration with contractors

Cooperation within the NPD department

Establishment of the LPS

Exhibitions

Extra-sectoral events

Fostering communication and sharing

Fostering creativity

Hired expert employees

Industry standards

In-house (informal) R\&D

Interaction with art direction

Interaction with certifying bodies

Interaction with consumers

Interaction with customers

Interaction with distribution channels

Interaction with education institutions

Interaction with external designer(s)
Interaction with external expert(s)

Interaction with internal designer(s)

Interaction with local actors

Interaction with Marketing department

Interaction with other departments

Interaction with partners

Interaction with Production department

Interaction with prototyping workshop

Interaction with suppliers

Internal procedures (e.g., ISO)

Internal restructuring

Internal training

Location

Organisational change (triggered by the LPS)

Past experience (regarding product development)

Past experience (regarding production)

Properties of materials

Real simulation exercises

Strategy-making 


\section{Appendix B}

Table B.1: Details of interviews conducted within the sampled firms

\begin{tabular}{|c|c|c|c|}
\hline A & Actors involved & Learning source & Root of learning \\
\hline \multicolumn{4}{|c|}{ 1. Fostering cooperation between the Production and the Product Development function } \\
\hline $\begin{array}{l}\text { Interaction with production } \\
\text { Interaction with prototyping workshop } \\
\text { Interaction with other functions (assemblers) } \\
\text { Interaction with Production \& Interaction } \\
\text { with local actors }\end{array}$ & $\begin{array}{l}\text { External designer, Prototyper, Production department } \\
\text { R\&D Director, Product Development department } \\
\text { Prototyper, R\&D Director, Production department } \\
\text { Production department, Communication department, } \\
\text { Marketing department }\end{array}$ & $\begin{array}{l}\text { NPD process } \\
\text { NPD process } \\
\text { NPD process } \\
\text { NPD process \& } \\
\text { Network }\end{array}$ & $\begin{array}{l}\text { Technological / } \\
\text { Operational }\end{array}$ \\
\hline \multicolumn{4}{|l|}{ 2. Carrying out product testing in-house } \\
\hline $\begin{array}{l}\text { Properties of materials } \\
\text { Interaction with certifying bodies } \\
\text { In-house (informal) } R \& D\end{array}$ & $\begin{array}{l}\text { Prototyping workshop, Production department } \\
\text { Quality Control unit, Certifying bodies, Production department } \\
\text { Product Development department, Art Director, External designer }\end{array}$ & $\begin{array}{l}\text { NPD process } \\
\text { NPD process } \\
\text { NPD process }\end{array}$ & \\
\hline \multicolumn{4}{|c|}{ 3. Gathering and managing relevant feedback } \\
\hline Interaction with customers & $\begin{array}{l}\text { Sales agents, Customer Service unit, Product Development } \\
\text { Department }\end{array}$ & Customer base & $\begin{array}{l}\text { Technological / } \\
\text { Operational }\end{array}$ \\
\hline Interaction with prototyping workshop & $\begin{array}{l}\text { Prototyping workshop, External designer, Product Development } \\
\text { department }\end{array}$ & Other internal resources & \\
\hline Interaction with suppliers & R\&D Director, Suppliers & Technology & \\
\hline Brainstorming & Board of Directors & Strategy-making & Strategic \\
\hline Interaction with customers & $\begin{array}{l}\text { Customer Care unit, Communication department, Product } \\
\text { Development department }\end{array}$ & Customer base & \\
\hline Exhibitions & Consumers, Product Development department & $\begin{array}{l}\text { External resources } \\
\text { (institutions) }\end{array}$ & Social \\
\hline
\end{tabular}


Table B.1 (continued)

\begin{tabular}{|c|c|c|c|}
\hline Event & Actors involved & Learning source & Root of learning \\
\hline \multicolumn{4}{|l|}{ 4. Fostering experimentation } \\
\hline In-house (informal) R\&D & $\begin{array}{l}\text { R\&D department, Materials expert, Product Development } \\
\text { department }\end{array}$ & NPD process & $\begin{array}{l}\text { Technological / } \\
\text { Operational }\end{array}$ \\
\hline Fostering creativity & $\begin{array}{l}\text { Board of Directors, Communication department, Marketing } \\
\text { department }\end{array}$ & Strategy-making & Strategic \\
\hline Brainstorming & Board of Directors, External Art Director & Strategy-making & \\
\hline Extra-sectoral events & R\&D department, Product Development department & $\begin{array}{l}\text { External resources } \\
\text { (institutions) }\end{array}$ & Social \\
\hline \multicolumn{4}{|c|}{ 5. Developing and benefiting from a network } \\
\hline Interaction with external designers & $\begin{array}{l}\text { External designers, Consumers, Art Director, President (and } \\
\text { internal designer) }\end{array}$ & Network & Social \\
\hline Interaction with suppliers & Suppliers, Art Director, Product Development department & Technology & \\
\hline Interaction with suppliers & Suppliers, R\&D department, Product Development department & Technology & $\begin{array}{l}\text { Technological / } \\
\text { Operational }\end{array}$ \\
\hline \multicolumn{4}{|c|}{ 6. Communicating the meaning (and value) of design } \\
\hline Fostering communication and sharing & $\begin{array}{l}\text { Board of Directors, Marketing department, Communication } \\
\text { department }\end{array}$ & Other internal resources & Social \\
\hline $\begin{array}{l}\text { Fostering communication and sharing } \\
\text { Interaction with distribution channels }\end{array}$ & $\begin{array}{l}\text { Board of Directors, President (and Art Director) } \\
\text { Board of Directors, Communication department, Product } \\
\text { Development department }\end{array}$ & $\begin{array}{l}\text { Other internal resources } \\
\text { Customer base }\end{array}$ & Strategic \\
\hline
\end{tabular}


Table B.2: Learning experiences behind product design capability building

\begin{tabular}{|c|c|c|}
\hline Type of learning & Learning experience & Description \\
\hline \multirow[t]{2}{*}{ Product characteristics } & Product Aesthetics (PA) & $\begin{array}{l}\text { Insight about product appearance or styling } \\
\text { (e.g., colour, type of varnish, mechanisms to open } \\
\text { a cabinet) }\end{array}$ \\
\hline & Product Functionality (PF) & $\begin{array}{l}\text { Insight about product features that define how a } \\
\text { particular product can perform and enable the user } \\
\text { to benefit from specific capabilities (e.g., range of } \\
\text { functions a product can serve such as sofa used } \\
\text { for both sitting and lying down) }\end{array}$ \\
\hline \multirow[t]{3}{*}{ Strategy } & $\begin{array}{l}\text { New Product } \\
\text { Development (NPD) }\end{array}$ & $\begin{array}{l}\text { Insight about the overall process of NPD, which } \\
\text { goes beyond the product functionality or aesthetics } \\
\text { and encompasses inputs to the development of the } \\
\text { brief, arrangements in place to communicate the } \\
\text { rationale of a given product innovation, etc. }\end{array}$ \\
\hline & Brand Image (BI) & $\begin{array}{l}\text { Insight about the market segments to target and } \\
\text { new techniques to develop for interacting with the } \\
\text { customer base (organisational innovation) }\end{array}$ \\
\hline & $\begin{array}{l}\text { Market / Marketing } \\
\text { techniques (M) }\end{array}$ & $\begin{array}{l}\text { Insight about the strategic approach to adopt for } \\
\text { introducing new products, processes or other types } \\
\text { of innovations }\end{array}$ \\
\hline Expertise & Skill Development (SD) & $\begin{array}{l}\text { Insight about the skills sets, whether the existing } \\
\text { ones need to be changed or integrated with new } \\
\text { expertise }\end{array}$ \\
\hline \multirow[t]{2}{*}{ Organisational issues } & $\begin{array}{l}\text { Organisational Structure } \\
(\mathrm{OS})\end{array}$ & $\begin{array}{l}\text { Insight about organisational changes at firm level } \\
\text { (e.g., new department, redesigning of the } \\
\text { hierarchical relationship between business } \\
\text { functions) }\end{array}$ \\
\hline & $\begin{array}{l}\text { Manufacturing Process } \\
\text { (MP) }\end{array}$ & $\begin{array}{l}\text { Insight as to how manufacturing processes should } \\
\text { be equipped / rearranged / modified for producing } \\
\text { a new prototype }\end{array}$ \\
\hline
\end{tabular}


Figure B.1: Fostering cooperation between the Production and the Product

\section{Development functions}

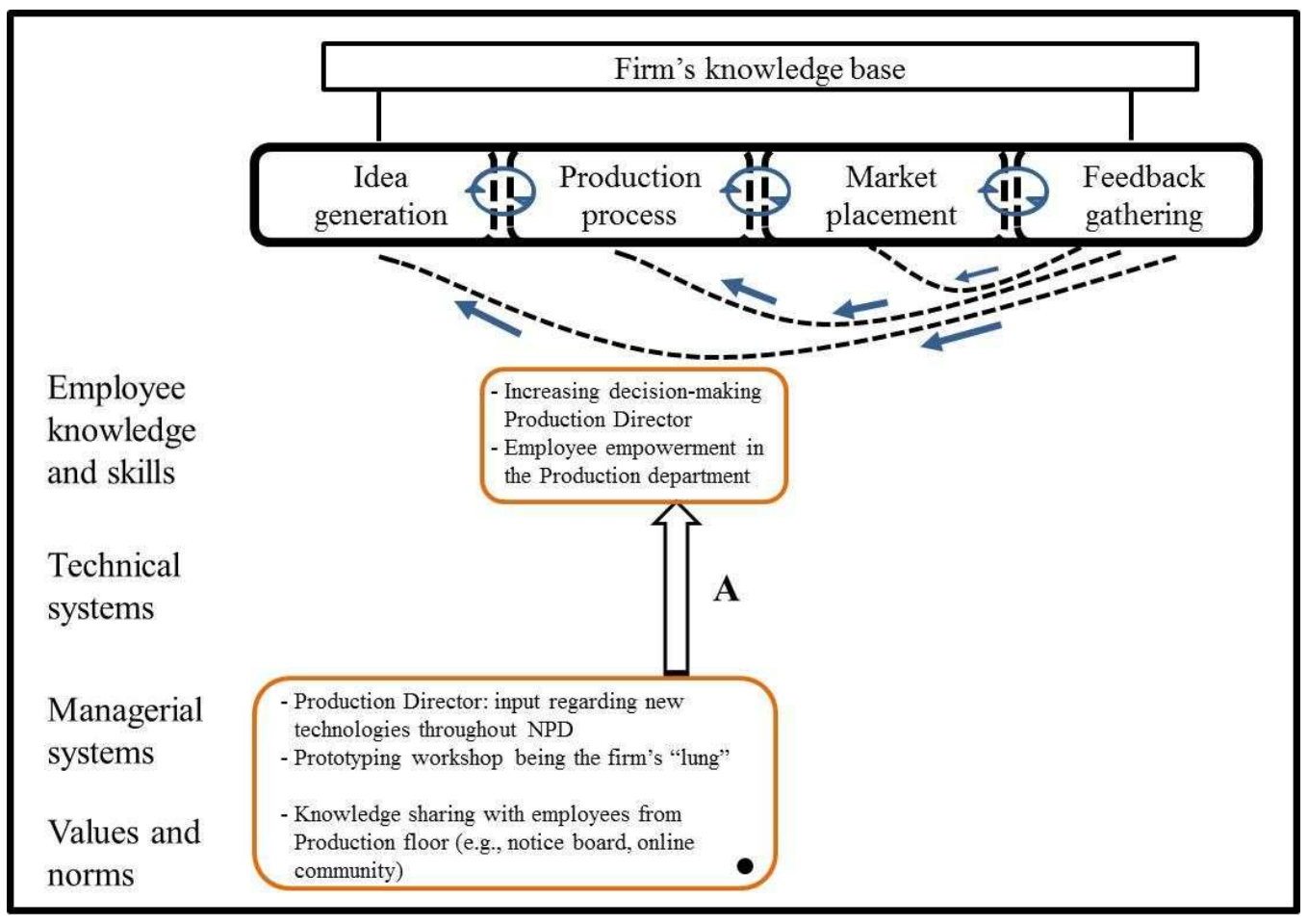

Figure B.2: Carrying out product testing in-house

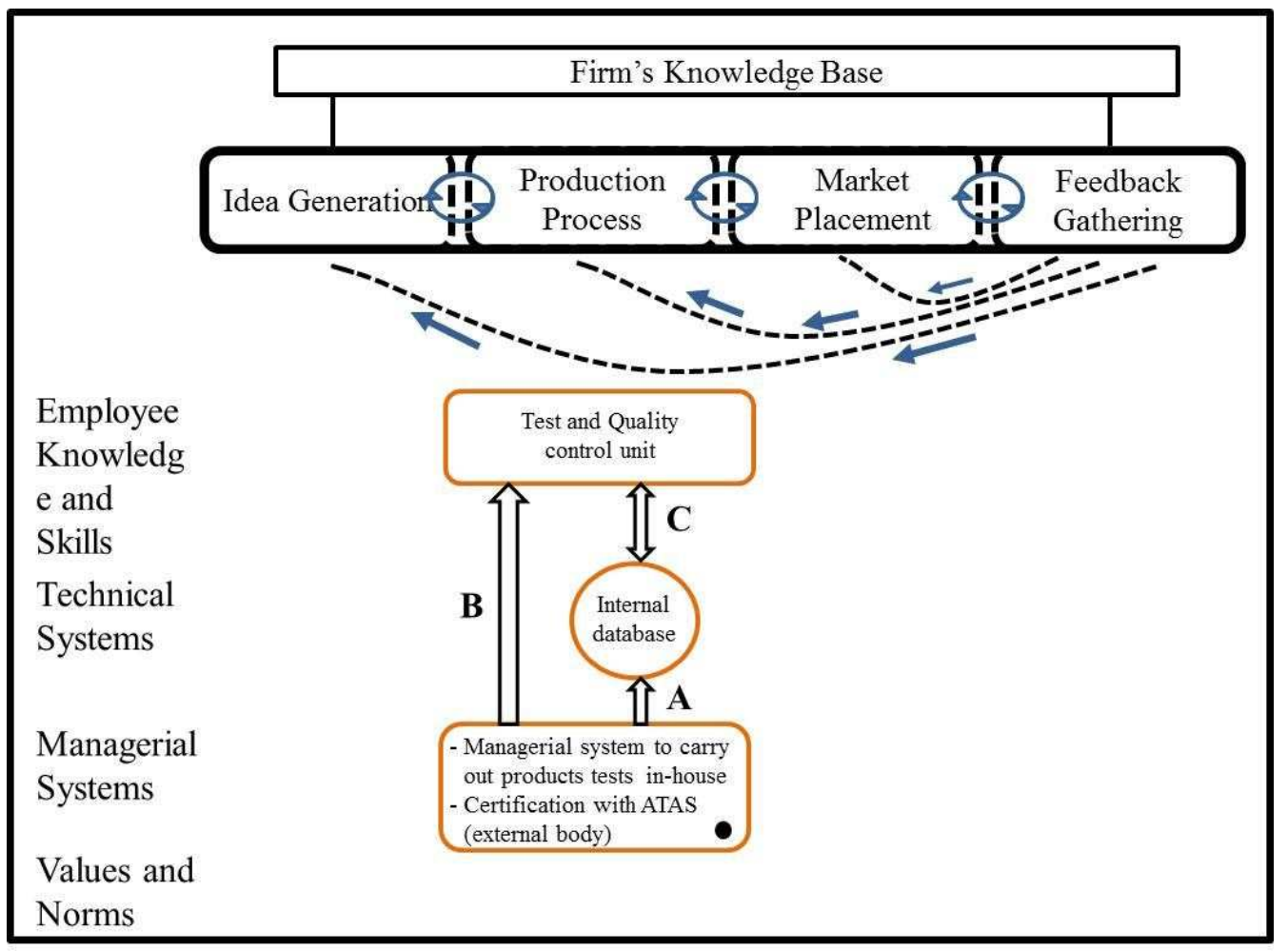


Figure B.3: Gathering and managing relevant feedback

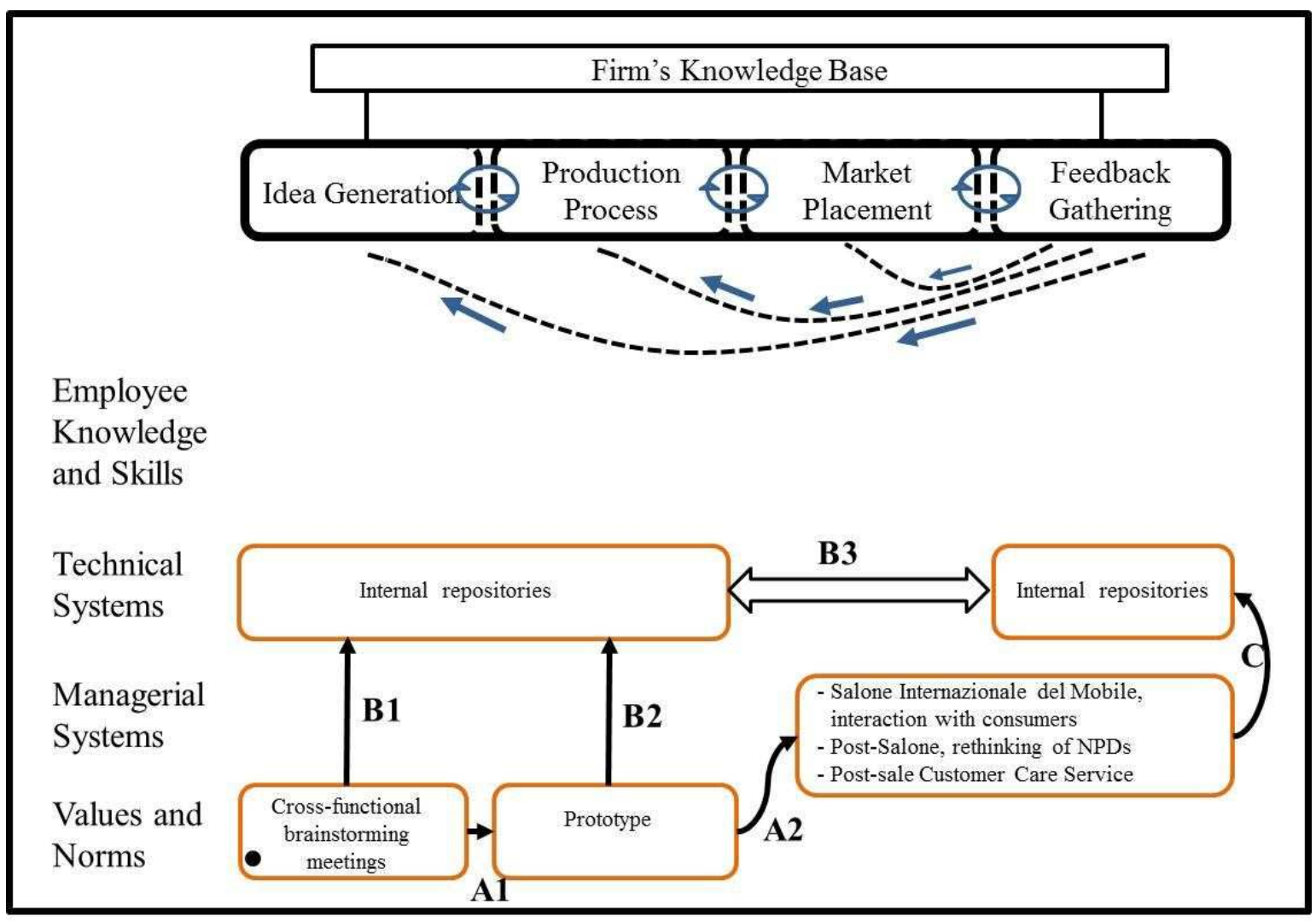

Figure B.4: Fostering experimentation

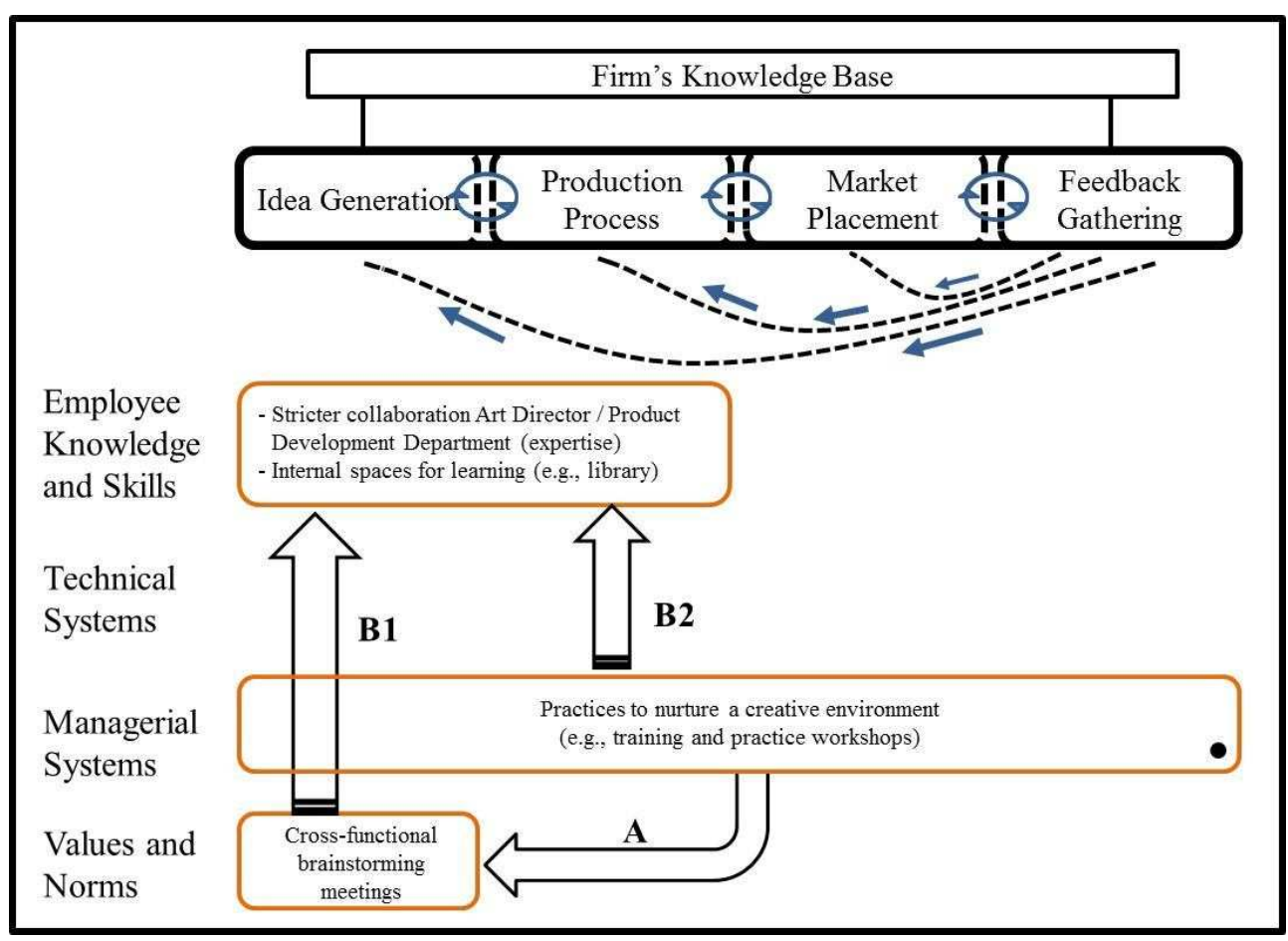


Figure B.5: Developing and benefiting from a network

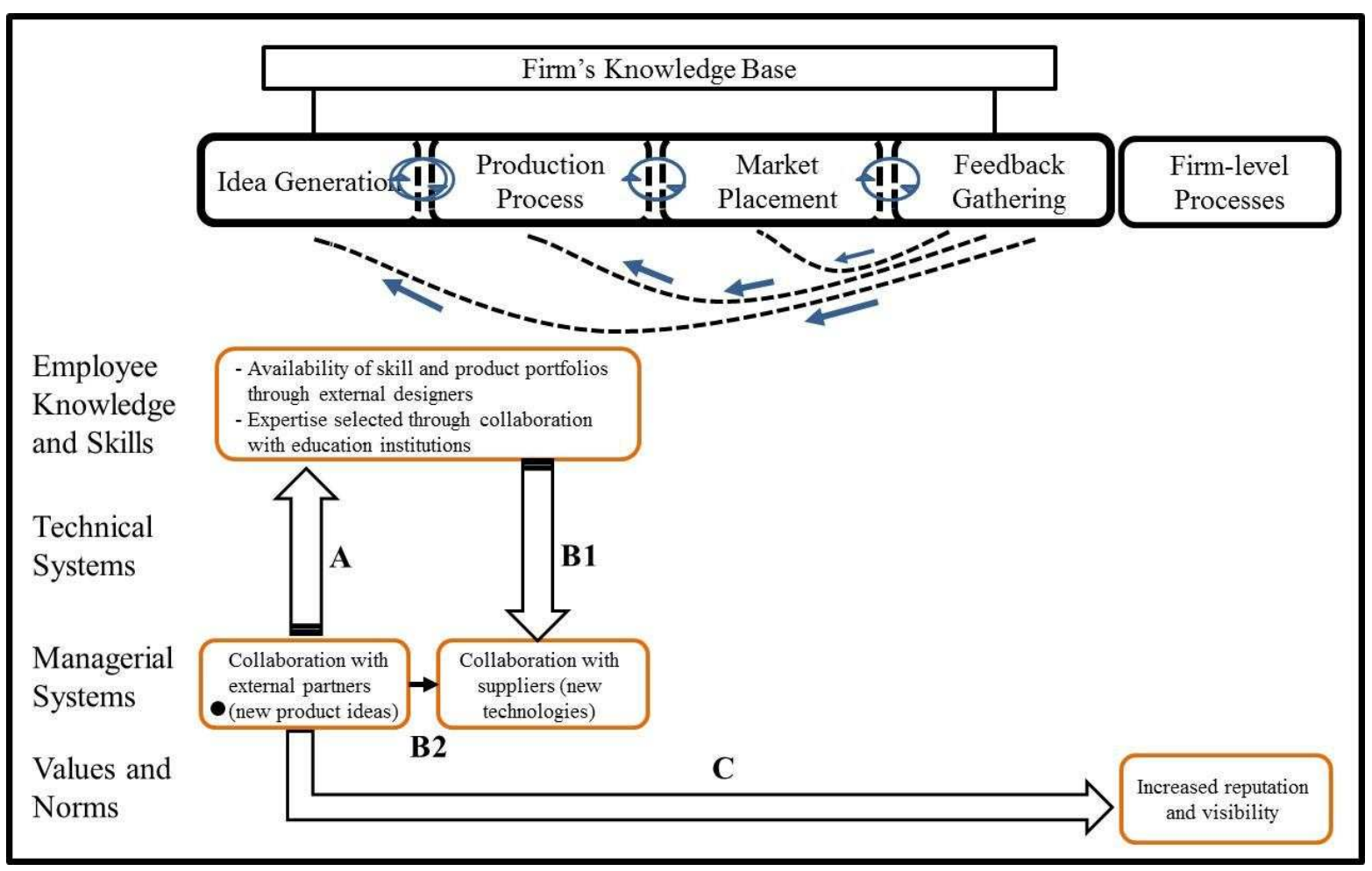

Figure B.6: Communicating the meaning and values of design

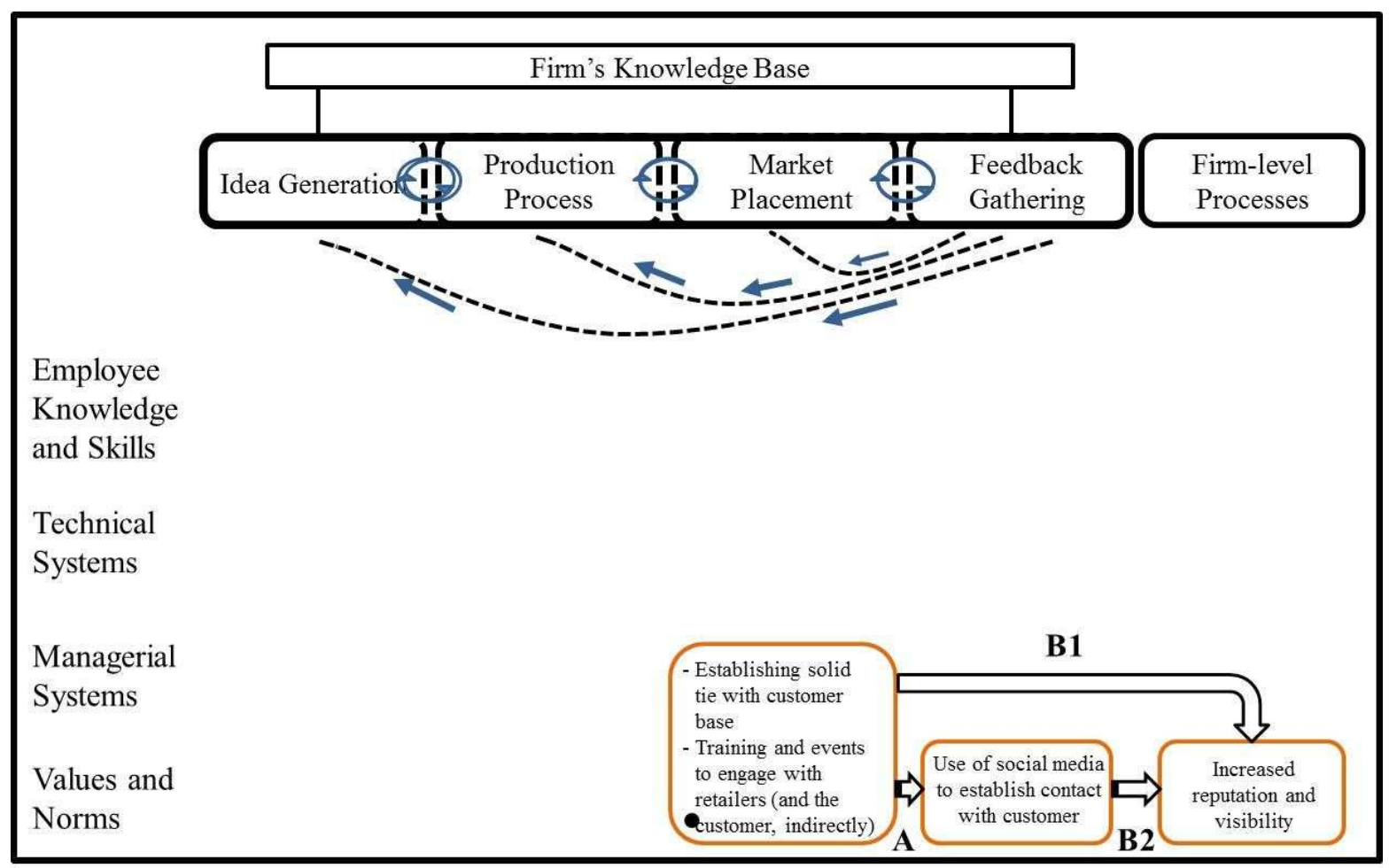

